\title{
INFLATION, INTEREST, AND THE SECULAR RISE IN WEALTH INEQUALITY IN THE U.S.: IS THE FED RESPONSIBLE?
}

\author{
Edward N. Wolff \\ Working Paper 29392 \\ http://www.nber.org/papers/w29392 \\ NATIONAL BUREAU OF ECONOMIC RESEARCH \\ 1050 Massachusetts Avenue \\ Cambridge, MA 02138 \\ October 2021
}

I would like to thank the C.V. Starr Center of Applied Economics at New York University for providing research support for this paper. The views expressed herein are those of the author and do not necessarily reflect the views of the National Bureau of Economic Research.

NBER working papers are circulated for discussion and comment purposes. They have not been peer-reviewed or been subject to the review by the NBER Board of Directors that accompanies official NBER publications.

(C) 2021 by Edward N. Wolff. All rights reserved. Short sections of text, not to exceed two paragraphs, may be quoted without explicit permission provided that full credit, including ( $)$ notice, is given to the source. 
Inflation, Interest, and the Secular Rise in Wealth Inequality in the U.S.: Is the Fed Responsible? Edward N. Wolff

NBER Working Paper No. 29392

October 2021

JEL No. D31,H31,J15

\begin{abstract}
Two hallmarks of U.S. monetary policy since the 1981-1982 recession have been declining interest rates and moderation in inflation. Coincident with these trends has been a surge in U.S. wealth inequality, with the Gini coefficient up by 0.070 between 1983 and 2019. This paper analyzes the connection between these two developments on the basis of the Survey of Consumer Finances. Contrary to expectations, the paper finds that these two monetary effects have reduced wealth inequality rather than increasing it. The effect is sizeable, with the Gini coefficient declining by 0.045 over these years. Asset price changes and debt devaluation accounted for 72.6 percent of the advance of mean wealth over 1983-2019. They also would have led to a 204.9 percent gain in median wealth, compared to the actual rise of 23.4 percent. Moreover, they have helped lower the racial wealth gap rather than enlarging it. These results are at odds with previous literature in which estimates range from a weak negative effect on inequality to neutral, small positive, and strong positive. In terms of methodology, this paper differs from previous work by focusing on only the direct effects of interest rate changes and inflation on the household balance sheet.
\end{abstract}

Edward N. Wolff

Department of Economics

New York University

19 W. 4th Street, 6th Floor

New York, NY 10012

and NBER

edward.wolff@nyu.edu 
Two hallmarks of U.S. monetary policy since the 1981-1982 recession have been declining interest rates and moderation in inflation. Wolff (2017, 2021), among others, has documented the sharp growth in U.S. wealth inequality over the same period, particularly since 1983, on the basis of the Survey of Consumer Finances (SCF). This study asks to what extent the decline in interest rates and the inflation rate can explain the rise in wealth inequality over the same period. That is to say, has monetary policy been responsible for the rise in wealth inequality in the U.S.?

Most studies which address the connection between inequality and monetary policy focus on income inequality but a few consider its effect on wealth inequality. Domanski et. al. (2016) reports that low interest rates had a negligible effect on wealth inequality in the Euro area and the U.S. Lenza and Slacalek (2018) find that quantitative easing (QE) compressed the income distribution in the euro area but that monetary policy had a negligible effect on wealth inequality. Bunn et al. (2018) find that the overall effect of accommodative monetary policy over the past decade or so in the UK on wealth inequality was equalizing though rather small. Greenwald et. al. (2021) using data for the U.S. from 1983 to 2016 find that the long-term decline in real interest rates led to a strong uptick in wealth inequality. Bartscher et. al. (2021), using data from the 2019 SCF, conclude that the accommodative monetary policy pursued in the U.S. exacerbated the racial income gap because Black households own relatively less financial assets than do white households (see Section 3 for a fuller literature review.) In contrast, I find a fairly substantial negative impact of monetary policy on wealth inequality for the U.S.

This paper develops a new model to examine the impact of interest rate and inflation rate changes on wealth inequality. The empirical analysis covers years 1983 to 2019 on the basis of the Federal Reserve Board's Survey of Consumer Finances (SCF). It also looks at the sensitivity of the results to alternative interest rate series based on U.S. Treasury bonds and mortgage rate data.

The paper contributes to the existing literature in two major ways. First, it develops a new methodology for analyzing the effects of monetary policy on wealth inequality. Second, in stark contrast to previous studies, it finds that monetary policy was not just equalizing but highly equalizing in terms of the distribution of wealth. It also finds that monetary policy actually reduced the racial wealth gap instead of increasing it. 
The rest of the paper is organized as follows. The next section, Section 2, provides some historical background on trends in interest rates, the inflation rate, and wealth inequality for the U.S. Section 3 offers a literature review on wealth inequality trends and the effects of monetary policy on inequality. Section 4 develops a new model connecting monetary policy to wealth inequality. Section 5 discusses the measurement of household wealth and describes the data sources used for this study. Section 6 presents results on time trends in wealth holdings and wealth inequality and highlights differences in portfolio composition by wealth class. Section 7 presents the key findings on the effects of interest rates and the inflation rate on household wealth trends. Section 8 provides a breakdown of the impacts of interest rate and inflation rate changes on net worth by race/ethnicity and Section 9 by age group. Section 10 analyzes the sensitivity of the results to alternative bond rate and mortgage rate series. Concluding remarks and policy implications are discussed in Section 11.

\section{Time Trends in Interest Rates, the Inflation Rate, and Wealth Inequality}

Figure 1 displays 10-year constant maturity Treasury annual bond nominal yields from 1953 to 2019. The time trends are quite revealing. After a more or less steady rise from a low of 2.40 percent in 1954 to a high of 13.92 percent in 1981, there followed a more or less steady decline to 2.14 percent in 2019. There was a particularly sharp decline between 1985 and 1986 from 10.62 to 7.67 percent. Figure 2 highlights trends since 2007 for different maturities. There are two points of interest. First, bond rates fell after 2007 but then bottomed out in 2016, rose from 2016 to 2018 as the Fed tightened up, but then declined from 2018 to 2019 as the Fed loosened up. The 10-year bond rate, in particular, dropped from 4.63 percent in 2007 to 1.84 percent in 2016, reversed course to 2.91 percent in 2018, and then dipped to 2.14 percent in 2019. Overall, interest rates fell rather precipitously. Second, changes were much sharper for shorter term bonds than longer term ones. Two-year bond rates, for example, plummeted from 4.86 to 0.59 percent between 2007 and 2016, popped up to 2.57 percent in 2018, and then declined to 1.78 percent in 2019.

Thirty-year mortgage rates display a very similar time trend (see Figure 3). There was a sharp rise in the interest rate from an average annual rate of 7.54 percent in 1971 (the first date for the data) to 16.64 percent in 1981, a slight decline to 16.04 percent in 1982, and then a pronounced and fairly continuous plunge to 7.31 percent in 1993 . This was followed by a modest uptick to 8.05 percent in 2000. Once again the interest rate declined rather continuously over 
time to 3.99 percent in 2017, reversed course somewhat to 4.54 percent in 2018, and then fell to 3.11 percent in 2020.

Trends in the inflation rate, based on the CPI-U-RS, seem to parallel those in interest rates (See Figure 4). The annual inflation rate shot up from 4.40 percent in 1978 to 11.20 percent in 1980 and then showed a generally downward drift to 1.81 percent in 2019. ${ }^{1}$ There were, of course, some deviations from this general trend. The inflation rate was down to 1.75 percent in 1986 and then bounced back to 4.93 percent in 1990. It then dropped to 1.35 percent in 1998, came back to 3.39 percent in 2000, fell to 1.58 percent in 2002, but was up to 3.39 percent in 2005.

Figure 5 provides further details for years 2007 to 2019. Once again, the inflation rate generally trended downward after 2007, from 2.84 percent to 1.81 percent. However, there were again dips and spikes. The rate went up to 3.84 percent in 2008 but then plummeted into negative territory at -0.35 percent in 2009. It then rebounded to 3.15 percent in 2011 , fell to 0.17 percent in 2015, climbed back to 2.44 percent in 2018, but then fell to 1.81 percent in 2019.

The real interest rate is defined here as the nominal interest rate minus the annual percentage change in the CPI-U-RS. As I will discuss in Section 4, the real interest rate is more appropriate for understanding the connection between monetary policy and household wealth movements than the nominal interest. As we just saw, nominal interest rates and the inflation rate generally trended downward after the early 1980s. What about the real interest rate? I show the trend in the 10-year constant maturity real Treasury bond rate in Figure 6. Surprisingly, the overall trend is quite similar to the nominal interest rate series. There is an upward trend from 4.01 percent in 1978 (the first date of the series) to a peak of 8.30 percent in 1984 and then a generally downward drift to 0.33 percent in 2019. However, as with the nominal interest rate series, there are many gyrations from this general trend. Among the more notable ones are a steep drop-off in the real interest rate from 4.01 percent in 1978 to -0.05 percent in 1979; an uptick from 3.35 percent in 1993 to 5.00 percent in 1994; a sharp rise from -0.08 percent in 2008 to 3.61 percent in 2009; and another steep climb from -0.37 in 2011 to 1.97 percent in 2015. It is next of interest to see how trends in the interest rates and inflation rate compare to wealth inequality trends. As shown in Figure 7, trends in household wealth inequality seem to be almost the exact inverse of trends in interest rates and inflation rate. The results show a strong

\footnotetext{
1 The CPI-U-RS series begins in 1977.
} 
upward trend in inequality over years 1983 to 2019 (more details will be provided in Section 6 below). The Gini coefficient rose from 0.799 to 0.869 and the share of the top decile from 68.2 to 78.1 percent. However, the trend was not continuous over time. There was an inequality spurt from 1983 to 1989, followed by relative constancy until 2007. There was then another surge in inequality lasting from 2007 to 2010 (coincident with the Great Recession) and a more modest upward drift after that.

\section{Literature Review}

I begin with a brief review of the literature on wealth inequality trends. Several studies document a surge in wealth inequality from the 1980s through the 2010s. Pfeffer et. al. (2013) make use of the Panel Study of Income Dynamics (PSID) and SCF data to analyze trends in wealth inequality over the Great Recession from 2007 to 2011. They find that all socioeconomic groups experienced declines in wealth following the recession, with higher wealth families experiencing larger absolute declines. However, in percentage terms the losses were greater for less advantaged groups as measured by minority status, education, and pre-recession income and wealth, leading to a substantial rise in wealth inequality in just a few years.

Saez and Zucman (2016), rather than relying on actual wealth survey data, convert income flows to stocks by taking the reciprocal of the rate of return and multiplying the flow (the so-called "capitalization method.”) With this method, they use federal income tax data to reconstruct the U.S. wealth distribution from 1913 to 2013. One of their most important findings is the sharp rise of the share of total household wealth owned by the top $0.1 \%$ from the beginning of the 1990 s from about $10 \%$ to about $15 \%$ at the end of the 1990 s. Subsequently, the top $0.1 \%$ wealth share climbed even more strongly to about 23\% in 2013.

This finding appears to be sensitive to the method and data used. Smith et al. (2019), for example, use the capitalization method but account for heterogeneity of rates of return within asset classes. This leads to a much smaller wealth share of the top $0.1 \%$ in 2013 of about $15 \%$. Bricker et al. (2015 and 2016b) use directly surveyed wealth data from the SCF augmented by the Forbes list of the 400 wealthiest Americans. They match some results of Saez and Zucman (2016), but their estimated share of the top 0.1\% for 2013 is about 6 percentage points lower. The trajectory of the top $0.1 \%$ wealth share in Bricker et al. (2015) more closely matches the series presented in Smith et al. (2019) than in Saez and Zucman. Bricker et al. (2016a and 2016b) 
reconcile estimates from the capitalization method and the SCF, showing that the deviations in estimates are driven by differences in variable definitions and differences in the unit of analysis.

Kopczuk (2015) compares estimates from the capitalization method with those from the mortality multiplier method that builds on estate tax data. A striking finding is that, until the early 1990s, both the capitalization and mortality multiplier estimates for the top $0.1 \%$ wealth share tracked each other very closely, but after this point the capitalization estimates climbed sharply while the mortality multiplier estimates remained flat. Kopczuk raises several issues why the methods arrive at different estimates. First, the unit of analysis differs, as the mortality multiplier estimates relate to individuals while the capitalization estimates relate to tax units. Second, personal debt is incorporated in the estate tax records but not in capital income. Third, assets that do not generate a positive return like state and local government bonds and debt must be imputed in the capitalization technique. For the top 10\% wealth share, Kopczuk (2015) documents a rise from the early 2000s, which is captured in both capitalization estimates and direct estimates from the SCF. Accordingly, the data seem to support a broad upward trend in wealth concentration. However, more finely grained analyses of the top $1 \%$ or the top $0.1 \%$ lead to diverging estimates across datasets and methods.

Other methods and other inequality indices offer evidence in support of the rising trend in wealth inequality. Wolff (2017) uses data from the SCF to show the evolution of the Gini index of net worth over time and finds a marked increase in the Gini from 2007 to 2010. He also finds an upward trend of the top 1\% wealth share from 2001 onward. Bricker et al. (2019) pursue imputation and augmentation techniques for the SCF, in particular a Pareto imputation of the top-tail and the augmentation by the Forbes 400 list. Both techniques increase the top 1\% wealth share by about 1.5 percentage points; for example from 39\% to $40 \%$ in 2016 . Bricker et al. (2019) also find the same upward trend in the top 1\% share found by Wolff (2017).

As noted above, most papers that look at the relation between monetary policy and inequality focus on income inequality, not wealth inequality. Moreover, among the latter, all studies to date take an indirect approach using regression analysis or calibration to estimate the effects of monetary policy on asset price movements. Among the former set of papers, Lenza and Slacalek (2018) find that QE compressed the income distribution in the euro area. Ampudia et.al. (2018) report that QE reduced income inequality in euro countries, while Davtyan (2016) concludes that contractionary monetary policy decreased income inequality in the U.S. Frost and 
Saiki (2014) look at the effect of unconventional monetary policy on income inequality in Japan using a vector autoregression (VAR) methodology. They find, using household survey data, that QE increased income inequality, especially after 2008. They also identify capital appreciation resulting from higher asset prices as the main factor.

Coibion et al. (2017) use quarterly data from the US Consumer Expenditure Survey in a VAR model with narrative shocks to estimate the effects of monetary policy on the Gini coefficient for income. They also report that expansionary monetary policy reduces inequality. Mumtaz and Theophilopoulou (2017) provide similar evidence for the UK and Guerello (2018) for the euro area. Furceri et al. (2018) use panel data from 32 advanced and emerging market economies and find that contractionary monetary policy shocks generally increase income inequality. Hafemann et al. (2018) analyse the effects of monetary policy on both gross and net income inequality in the US, Canada, South Korea, Sweden, the Czech Republic and Hungary. They find that that the disequalizing effects of expansionary monetary policy on the market income distribution are mitigated if the degree of redistribution is high.

Casiraghi et al. (2018) use Italian data and Bunn et al. (2018) use data from the UK to analyze unconventional monetary policy. The former find that larger benefits from ECB's unconventional monetary policy accrue to the bottom of the income scale, as the gains from the stimulus to economic activity and employment outweigh losses from financial markets, while the latter find that the overall effect of monetary policy on income inequality was quite small. Amberg et. al. (2021), using Swedish administrative data over the period 1999- 2018, conclude that the effects of monetary policy shocks are U-shaped with respect to the income distribution, In particular, expansionary shocks increase the incomes of high- and low-income individuals relative to middle-income individuals. The large effects on the bottom are due to the laborincome response and those at the top by the capital-income response.

In the latter literature on the relationship between monetary policy and wealth inequality, an early paper by Wolff (1979) assesses the impact of inflation on the distribution of wealth in the U.S. over the 1969-1975 period. Because of the strong negative correlation between wealth level and the ratio of debt to wealth, this particular inflation induced a substantial drop in the overall level of wealth inequality, with the Gini coefficient dropping from 0.78 to 0.73 . Moreover, comparing the portfolios of different demographic groups, he finds that middle-aged households gained relatively to younger and older ones, married couples gained relatively to 
singles, whites gained relatively to non-whites, and home-owners gained relatively to renters. The biggest gainers from this inflation were home-owners with large mortgages and the biggest losers the large stock holders.

Gabriel and Lutz (2017) analyse the relationship between interest rates and house prices. They find that lower interest rates in the U.S. led to higher real estate prices. Their analysis is based on a structural factor-augmented vector autoregression (FAVAR) model and a dataset of daily time series on housing, real estate, and related markets in the 2000s. The effect of an expansionary unconventional monetary shock on housing and related prices is estimated indirectly using econometric techniques rather than directly as done in this paper. There is also no analysis of the effects of inflation on housing prices.

Domanski et. al. (2016) conclude that low interest rates had a negligible effect on wealth inequality in the Euro area and the U.S. whereas stock price movements particularly and home price trends secondarily did have a major impact on wealth inequality trends. Their empirical work covers years 2003 to 2015 for France, Germany, Italy, Spain, the U.K. and the U.S. They first report an uptick in wealth inequality for France, Germany, the U.K., and the U.S. since the Great Recession (about year 2007) but not for Italy and Spain. They find that low interest rates and rising bond prices had very little impact on wealth inequality trends but the main driver was rising equity prices. They surmise that "monetary policy may have added to inequality to the extent that it has boosted equity prices [page 45]." However, their methodology is based on actual market returns on individual assets and they do not provide a direct connection between interest rates and equity values, as I do in this paper. Their analysis is also conducted for a single year and they do not account for the effects of inflation. ${ }^{2}$

Lenza and Slacalek (2018) report that monetary policy had a negligible effect on wealth inequality. Their paper estimates the effects of QE using a multi-country VAR model of the four largest euro area countries, in which key variables affecting household income and wealth are included, such as wages, interest rates, house prices and stock prices. The aggregate effects are distributed across the individual households by means of a reduced-form simulation on micro

\footnotetext{
${ }^{22}$ Another problem is that they exclude pension accounts, like 401(k) plans in their empirical analysis because of a lack of comparable data. This is particularly a problem for the case of the U.S. where pension accounts made up 15.6 percent of total assets in 2007.
} 
data from the Household Finance and Consumption Survey (HFCS). Here, too, the analysis is indirect, relying on econometric analysis of actual price and income data.

Bunn et al. (2018) find that the overall effect of accommodative monetary policy over the past decade or so in the UK on wealth inequality was equalizing but rather small. The paper uses panel data from the Office of National Statistics (ONS) Wealth and Assets Survey (WAS) to estimate the distributional impacts of UK monetary policy between 2008 and 2014 and elasticities from a large-scale econometric model of the UK economy to assess the aggregate effects of QE. On the basis of the pre-existing disparities in wealth, they estimate that the impact on each household varied substantially across the income and wealth distributions in cash terms, but in percentage terms the effects were broadly similar. However, the paper does find that monetary policy was equalizing, lowering the Gini coefficient for net worth in 2012-2014 of 0.612 by 0.017 . Increases in the value of financial wealth on account of monetary policy/low interest rates are estimated to raise wealth inequality since the rich hold a higher share of these assets in their portfolio but those effects are more than offset by housing wealth and the effects of inflation acting in the opposite direction and helping to reduce the Gini coefficient. Once again, the analysis is indirect, relying on econometric analysis of asset pricing, though the authors do incorporate the effects of inflation on the real value of debt.

Using hypothetical scenarios, Adam and Tzamourani (2016) quantify the effects of a 10 percent price increase of stocks, bonds, and houses on the wealth distribution of euro area households using data from the HFCS. In particular, the paper evaluates the impact of standard monetary policy on wealth by using the impulse response of asset prices estimated by Peersman and Smets (2001) on synthetic euro area data for the pre-euro period, 1980-1998. The paper finds that capital gains from equity price increases are concentrated among the rich, while housing price increases strongly benefit the middle class. The capital gains from bond price increases do not correlate with household net wealth. However, no result is reported on the overall wealth distribution and there is no consideration of the effects of inflation.

Andersen et. al. (2021) use administrative individual-level tax records for the entire population in Denmark with detailed information about income and balance sheets for the period 1987-2014 to analyze the effects of softer monetary policy on wealth gains by income class instead of by wealth level. The paper considers the various direct and indirect channels of monetary policy. It consistently finds that gains from softer monetary policy in terms of wealth 
are monotonically increasing in the ex ante income level. Using various econometric techniques, the estimates capture the "price effects" of monetary policy on asset values through changes in house prices and stock prices holding ex ante portfolios constant, but not the effect working through changes in the portfolios. The estimated effects are positive at all income levels: softer monetary policy boosts asset prices. Softer monetary policy increases the value of housing assets at all income levels and the magnitude of the effect is monotonically increasing in income: the estimated gain is around 20 percent of disposable income at the bottom of the income distribution and around 50 percent at the top. It also increases stock values but the gains are highly concentrated at the top of the income distribution: the estimated gain is around 15 percent of disposable income in the top income group and entirely negligible below the median income level. Altogether, there is a clear income gradient in the effects: a one percentage point decrease in the policy interest rate increases asset values by around 20 percent of disposable income at the bottom of the income distribution and by around 75 percent at the top over a two-year horizon. Measured relative to total asset values, the estimated effects range from around 6 percent at the bottom to around 8 percent at the top. The analysis includes the effect of inflation on household debt.

Greenwald et. al. (2021) using data from the SCF from 1983 to 2016 find that the longterm decline in real interest rates led to a strong uptick in financial wealth inequality in the U.S. from the 1980s to the 2010s. The authors attribute this mainly to the fact that high financialwealth households have a financial portfolio with long duration. They define financial wealth as the sum of cash and deposits, equities, real estate, private business wealth, and fixed income securities less mortgage debt, student debt, and other debt. They calibrate the duration of financial wealth for the U.S. using data from the SCF and an auxiliary asset pricing model for each asset type. (In contrast, my paper assumes different bond and mortgage durations.) Their model almost exactly reproduces the rise in the financial wealth Gini coefficient from 0.804 in the 1980 s to 0.873 in the 2010s. However, their analysis does not consider the direct effects of inflation. Their method is also indirect, based on the calibration of a simulation model. ${ }^{3}$

\footnotetext{
${ }^{3}$ A related paper on the subject is Matthieu and Gouin-Bonenfant (2020). They argue that while low rates decrease the average growth rate of existing fortunes, they increase the growth rate of new fortunes by making it cheaper to raise capital. Which effect dominates depends on the average equity issuance rate and leverage of individuals on the right tail of the distribution. They estimate this using new data on the trajectory of the fortunes of the top 100
} 
Bartscher et. al. (2021), using data for a single year from the SCF, 2019, focus on portfolio differences between Black and white households. They find, as I do here, that the former hold relatively less of their wealth in financial assets than the latter. As a result, a rise in the value of financial assets will lead to relatively greater gains among white households and widen the wealth gap. The empirical analysis in this paper is also indirect, based on linking asset price changes to "monetary policy shock series.” The authors employ instrumental variable local projections (LP-IV) to estimate the effect of monetary policy changes on the prices of stocks, equities, and other financial assets. They find that a typical accommodative monetary policy shock leads to capital gains equivalent to 20-30 percent of white mean income but about 10 percent of Black mean income. The effect stems mainly through stock price gains. House price gains also disproportionately benefit white households even though Blacks hold a higher share of their assets in housing. However, this paper does not consider the effects of inflation on relative wealth holdings nor does it directly address the racial wealth gap.

This paper contributes to the existing literature in four ways. First, its main contribution is to develop a new, and, I believe, more appropriate, methodology to isolate the effects of both interest rates and the inflation rate on the household balance sheet. In particular, it looks at the direct effects of monetary policy on wealth movements by establishing a direct analytical linkage between the interest and inflation rates on stock and other asset prices. Second, the analysis covers years 1983 to 2019, whereas the other papers cover considerably shorter time periods. Third, results are shown separately for six sub-periods - 1983-1989, 1989-2001, 2001-2007, 2007-2010, 2010-2016, and 2016-2019 - as well as for the full time period, 1983-2019. Fourth, the principal finding reported here is that expansionary monetary policy has sharply reduced wealth inequality, in contrast with the several studies that find a small equalizing, neutral, small disequalizing, or strong disequalizing effect on wealth inequality.

\section{The Model}

\section{$\underline{4.1 \text { Capital Asset Values }}$}

There are various channels through which a change in the interest rate affects asset values. First, for stocks, the present discounted value of future corporate earnings will rise if the

individuals in the U.S. and conclude that the secular decline in interest rates played a key role in the recent increase of top wealth inequality. 
interest rate falls and the (current) stock price should in principle be proportional to the present value of future earnings. In particular, since the price that an asset A, $\mathrm{p}_{\mathrm{A}}$, will command on capital markets is determined by the net present value of expected receipts from that asset,

(1) $\mathrm{pA}_{\mathrm{A}}=\sum_{t=0}^{T} \frac{Y_{t A}}{(1+r)^{t}}$,

where $\mathrm{t}$ is time, $\mathrm{T}$ is the time horizon, $\mathrm{Y}_{\mathrm{tA}}$ is the expected revenue at time $\mathrm{t}$, and $\mathrm{r}$ is the interest rate, asset values move inversely to interest rate changes. However, since the net present value of any alternate asset $\mathrm{B}$ is given by:

$$
\text { (2) } \mathrm{pв}=\sum_{t=0}^{T} \frac{Y_{t B}}{(1+r)^{t}}
$$

which has a different time pattern and/or duration of future receipts $\left(\frac{Y_{t A}}{Y_{t B}} \neq 1\right)$, pв will not move exactly proportionately with $\mathrm{pA}$, and interest rate changes will differentially affect the relative values of different asset types. Therefore, since the composition of wealth holdings varies with wealth levels-- e.g. the wealth of middle deciles of the wealth distribution is largely in residential real estate while financial assets dominate the portfolios of the top wealth percentile (see Section 6 below) -- changes in interest rates affect both the level and the inequality of wealth.

While it is true that a decline in the interest rate will generally boost stock prices, this is a direct effect only. It is likely the case that actual stock prices depend more on the expected revenue flow from the asset than the interest rate. Of course, there are many factors that affect future revenue flow (and expected future revenue flow), and the expected earnings stream can shift (widely) over time. ${ }^{4}$ The same logic applies to the value of (unincorporated) business assets, which is another important component of the household portfolio. The value of unincorporated business tends to follow the stock market. A fall in interest rates produces a rise in the present value of future business profit flows, which raises the market value of businesses.

\subsection{Bond values}

For financial securities, since bond values increase when the interest rate falls, the relationship is tighter and can be calculated directly. A one-year bond that promises to

\footnotetext{
${ }^{4}$ In particular, Fed policy like a change in the Federal funds rate may affect stockholders' expectation of future profits flows and therefore stock values. However, this is an indirect effect of Fed policy and is ignored in my analysis.
} 
make only a single payment of \$X in one year (principal plus interest) will have a price, $\mathrm{P}_{\mathrm{BX} 1}$, that depends on the market interest rate, $\mathrm{r}$, as follows: $\mathrm{P}_{\mathrm{BX} 1}=\mathrm{X} /(1+\mathrm{r})$.

Actual bonds typically promise a fixed interest payment, called the coupon payment, $\mathrm{C}$, each year until maturity, then pay back the entire principal, $\mathrm{P}_{0}$, in the year the bond matures. If the term to maturity of the bond is denoted $\mathrm{T}$, then the price (present value) of the bond is:

$$
\text { (3) } \mathrm{P}_{\mathrm{b}}=\mathrm{C} /(1+\mathrm{r})+\mathrm{C} /(1+\mathrm{r})^{2}+\ldots+\mathrm{C} /(1+\mathrm{r})^{\mathrm{T}}+\mathrm{P}_{0} /(1+\mathrm{r})^{\mathrm{T}}
$$

Since the amount of bonds held by households is low relative to total assets, this is likely to have a rather small effect on total household wealth - but since bonds are disproportionately held by the very affluent, it will affect wealth inequality.

IRAs, 401(k) plans, and other defined contribution holdings are typically a mixture of bonds, stocks, money market funds, and other assets. If the interest rate falls, the change in its value will be a weighted average of the change in the individual asset components. In the empirical analysis in Section 6, I construct “consolidated” portfolio accounts for each wealth group in which stocks and bonds owned indirectly through pension accounts (and also mutual funds and trust funds) are broken down into their constituent components

\section{$\underline{4.3 \text { Real Estate Values }}$}

House prices and other real estate values depend mainly on both capital gains expectations and how much their value reacts to changes in mortgage carrying costs. Generally speaking, the mortgage interest rate tracks movements in the ten-year Treasury bill rate as was shown in Section 2. If the mortgage interest rate falls as a result of a decline in the Treasury bill rate, then real estate carrying costs will decline, producing a rise in demand for real estate and increased real estate prices. As with bonds and stocks, I consider here only the direct effects of a change in interest rates on real estate values. There are other factors that influence real estate values like capital gains expectations, as noted above. ${ }^{5}$

There is a direct connection between mortgage rates and house price in terms of affordability. Most home buyers who use a mortgage loan to finance their purchase will need to put down a certain percentage of the sale price. The standard is 20 percent down; however,

\footnotetext{
${ }^{5}$ See, for example, Duca and Muellbauer (2021) for an extensive discussion of the factors that affect house and real estate prices.
} 
the median down payment for U.S. buyers was 12 percent in 2020, according to the National Association of Realtors. On a conventional loan, it is possible to go as low as 3 percent. If a person gets a 30-year fixed-rate mortgage for $\$ 200,000$ with an interest rate of 4 percent, the monthly payment will be about $\$ 955$. Contrast this with a $\$ 200,000$ loan at 3.5 percent, with which the monthly payment is $\$ 898$, a \$57 difference each month. Over 30 years, the person will have paid the lender an additional \$143,739 in interest on the 4.0 percent loan, and only $\$ 123,312$ on the 3.5 percent loan.

Figure 8 illustrates the trade-off between home price and the annual mortgage rate, which shows equivalent monthly payments based on a 30-year fixed rate mortgage with a 20 percent down payment and monthly payments. At a 6.5 percent mortgage interest rate, a $\$ 100,000$ home will result in the same monthly payment as a $\$ 125,000$ home with a 4.5 percent mortgage rate. That is to say, with a 6.5 percent interest rate, a family could afford the same monthly payment as a house worth 25 percent more with a 4.5 percent interest rate. This trade-off thus reflects the effect of mortgage rates on home prices. I will use this relationship in the simulation analysis in Section 7.

This analysis shows the direct asset price effect of a change in the mortgage rate. It essentially says that if a given family could afford to pay $\$ 100,000$ for a home at a 6.5 percent mortgage interest rate, it would be willing to pay $\$ 125,000$ at a 4.5 percent mortgage interest rate. Presumably, a drop in the mortgage rate will increase the demand for housing and thereby home prices.

On the liability side, for current homeowners with variable rate mortgages, servicing costs go down when interest rates decline (usually pegged to the prime rate) though the face value of mortgage debt remains unchanged. Homeowners with fixed rate mortgages usually have the option to refinance at the lower mortgage rate so that their carrying costs also go down (minus closing costs and other refinancing fees). Since there is a decline in the present value of their cash outflow, mortgage holders get an effective capital gain when interest rates decline. On the other hand, homeowners without mortgages are unaffected by a decline in mortgage rates. In the accounting framework here, reduced carrying costs for mortgage holders shows up as an expenditure effect, not a wealth effect. The rationale is that from a balance sheet point of view, the outstanding debt remains unchanged, so net worth is unaffected. It is, of course, possible that the lowered expenditures could show up as enhanced savings but this will be reflected in the 
purchase of additional assets and therefore greater net worth. To the extent that interest rates on other debts move with the Treasury bill rate or prime interest rate, the same argument holds true for other loans as well. ${ }^{6}$

\subsection{Liquid Assets}

The face value of liquid assets like bank accounts does not change when interest rates change. That is to say, unlike bond values, the marketable value of a liquid asset is not altered when the interest rate goes up or down, so that the household balance sheet is unaffected. However, it is true that a change in the Federal funds rate may affect the interest rate that liquid assets such as a bank account may pay. Since the objective of this analysis is to analyze the direct effects of Fed actions on wealth inequality, it may make sense to also include the Fed's effect on the accumulation of liquid assets over time. In the base case, I exclude this effect but in the sensitivity analysis in Section 10 I include this effect. In either case, the real value of liquid assets will change from overall inflation. When the inflation rate is high, the real value of liquid assets will depreciate more over time than when inflation is low.

\subsection{The Inflation Rate}

The inflation rate comes into play in four ways. First, inflation reduces the real value of household debt. Therefore, an increase in the inflation rate will lead to greater growth in mean and median household net worth. Second, as we shall see in Section 6, relative indebtedness as measured by the debt-net worth ratio is significantly higher for middle class families than rich ones. As a result, inflation acts as an equalizing force, reducing wealth inequality. For example, Wolff (1979) assesses the impact of inflation on the distribution of wealth during the 1969-1975 period. Because of the strong negative correlation between wealth level and the ratio of debt to wealth, this particular inflation induced a substantial drop in the overall level of wealth inequality. Third, it affects the real interest rate. A fall in the inflation rate will lead to a decline in the real interest rate. Fourth, as noted above, the inflation rate affects the real value of liquid assets.

\subsection{Real versus Nominal Interest Rate}

\footnotetext{
${ }^{6}$ It should be noted that homeowners with larger mortgages will benefit more from the mortgage interest rate reduction than those with smaller mortgages or no mortgages. In distributional terms, richer households will generally benefit more. It should also be noted that my approach differs from several papers cited above which include mortgage payments as a negative wealth entry. This paper does not do that. Mortgage payments are an income flow and do not affect the balance sheet except for amortization.
} 
So far, I have skirted the issue of whether "r" in the present value and bond formula (equations 1, 2, and 3) is the real or nominal interest rate. The answer is the real interest rate. To see this, consider the fact that the earnings stream $Y_{t}$ must be in real terms. ${ }^{7}$ Likewise, for bonds the coupon rate $\mathrm{C}$ must be in real terms. Otherwise, in the former case, a simple rise in the inflation rate would result in a rise in $\mathrm{pA}$ even though real future earnings have remained unchanged. The same logic applies to bond values and holds for valuing unincorporated businesses.

The logic is different for the effect of mortgage rates on house prices. In this case, as shown above, a change in the nominal mortgage rate will translate directly into a change in the current monthly mortgage payment, which will affect the affordability of the property and therefore its (current) price. The house price should vary according to the differential in the nominal interest rate.

Table 1 shows the time trends in the key ingredients for the analysis of the effect of monetary policy on inequality, where the percentage change in prices have been converted to an annual rate of change. It is first of interest to look at the results for the full period, 1983-2019. By far the fastest rate of increase occurred for home prices and debt, 2.40 and 2.49 percent per year, respectively. ${ }^{8}$ This was followed by real bond values, at 1.64 percent per year, and then the present value of real future profits, at 0.74 percent per year. In contrast, the real value of liquid assets declined at an average annual rate of 2.49 percent, mirroring that of the CPI-U-RS index. These differentials will play a key role in affecting wealth inequality trends, with changes in house prices and debt favoring the middle class and those in bonds and profits favoring the rich, since, as we shall see below, the former have a much higher share of assets in their homes and a higher debt burden while the rich have a larger share in financial assets and businesses. On the other hand, the middle class has a higher share of assets in liquid assets, so that the decline in its value will hurt the middle class more than the rich. However, on net it appears that Fed policy is likely to have benefited the middle class more than the rich.

\footnotetext{
${ }^{7}$ This is analogous to the Campbell-Shiller CAPE ratio, the ratio of stock price per share deflated by the consumer price index to the average value over the past 10 years of corporate earnings per share deflated by the CPI (see Campbell and Shiller Campbell, 1998). The Excess CAPE Yield (ECY) is likewise based in part on real long-term interest rates (see Shiller et. al., 2020).

${ }^{8}$ Indeed, according to my calculations, the reduction in mortgage rates account for almost the whole increase in actual median home prices over years 1983-2019.
} 
It is also of note that when comparing real and nominal trends, differences are relatively small for the 1983-2019 period. The annual rate of change in the nominal value of bonds was 1.64 percent, compared to 1.41 percent for real values, and those in future profits were 0.93 and 0.74 percent, respectively. The higher values for the nominal series are due to the fact that the differential between the nominal and real rate of change narrowed over these years because the inflation rate fell over these years.

The time pattern of annual rates of change also plays a critical role. They generally trended downward over time. It is apparent that the highest rate of change occurred in the earliest period, 1983-1989, for real bond values, real future profits, and the inflation rate and it ranked second highest for home prices. For real bond values and real future profits, returns fell in 19892001 and again in 2001-2007, flattened out in 2007-2010, rose in 2010-2016, and then fell again in 2016-2019. Home price gains likewise declined in 1989-2001 and again in 2001-2007, spiked in 2007-2010 due to a sharp drop in mortgage rates, fell sharply in 2010-2016, and then turned negative in 2016-2019. The inflation rate also fell between the first period and 1989-2001, flattened out in 2001-2007, dropped in 2007-2010, stayed steady in 2010-2016, and then rose somewhat in 2016-2019. As a result, the real value of liquid assets experienced its greatest decline in the first period, fell successively less through 2010-2016, and then decreased somewhat more in 2016-2019.

\section{Data sources and methods}

The primary data sources used for this study are the 1983, 1989, 1992, 1995, 1998, 2001, 2004, 2007, 2010, 2013, 2016, and 2019 SCF. Each survey consists of a core representative sample combined with a high-income supplement. Starting in 1989, the first sample was selected from a standard multi-stage area-probability design. This part of the sample was intended to provide good coverage of asset characteristics such as home ownership that are broadly distributed. The second sample, the high income supplement, is selected as a so-called "list sample" from statistical records (the Individual Tax File) derived from tax data by the Statistics of Income (SOI) Division of the Internal Revenue Service. In this case, the IRS provided the names and addresses of a sample of very high income families. This second sample was designed to disproportionately select families that were likely to be relatively wealthy (see, for example, Kennickell and Woodburn. 1999). The advantage of the high-income supplement is that it provides a much "richer" sample of high income and therefore potentially very wealthy families. 
However, the presence of a high-income supplement creates some complications, because weights must be constructed to meld the high-income supplement with the core sample. Typically, about two thirds of the cases come from the representative sample and one third from the high-income supplement. In the 2007 SCF the standard multi-stage area-probability sample contributed 2,915 cases while the high-income supplement contributed another 1,507 cases.

The wealth concept used here is marketable wealth (or net worth), which is defined as the current value of all marketable or fungible assets less the current value of debts. Net worth is thus the difference in value between total assets and total liabilities. Total assets are defined as the sum of: (1) owner-occupied housing; (2) other real estate; (3) bank deposits, certificates of deposit, and money market accounts; (4) government and corporate bonds and other financial securities; (5) the cash surrender value of life insurance plans; (6) defined contribution (DC) pension plans, including IRAs and 401(k) plans; (7) corporate stock and mutual funds; (8) unincorporated businesses; and (9) trust funds. Total liabilities are the sum of: (1) mortgage debt, (2) consumer debt, and (3) other debt such as educational loans.

This measure reflects wealth as a store of value and therefore a source of potential consumption. I believe that this is the concept that best reflects the level of well-being associated with a family's holdings. Thus, only assets that can be readily converted to cash (that is, "fungible" ones) are included. Though the SCF includes information on the value of vehicles owned by the household, I exclude this from my standard definition of household wealth, since their resale value typically far understates the value of their consumption services to the household. The value of other consumer durables such as televisions, furniture, household appliances, and the like are not included in the SCF. ${ }^{9}$ Another justification for their exclusion is that this treatment is consistent with the national accounts, where purchase of vehicles and other consumer durables is counted as expenditures, not savings. A further reason is that for most people the concept of wealth as a store of potential consumption means that one should exclude assets whose possession is required in order to enable consumption or to earn income - for example, cars which are needed to purchase groceries or go to work.

\footnotetext{
${ }^{9}$ On the other hand, the value of antiques, jewelry, art objects and other "valuables" are included in the SCF in the category "other assets."
} 
Also excluded here is the value of future Social Security benefits the family may receive upon retirement ("Social Security wealth"), as well as the value of retirement benefits from defined benefit pension plans ("DB pension wealth"). Even though these funds are a source of future income to families, they are not in their direct control and cannot be marketed. ${ }^{10}$

\section{Wealth trends, 1983-2019}

Table 2 documents a robust growth in wealth from 1983 to 2007 (also see Figure 9). Median wealth increased at an annual rate of 1.13 percent from 1983 to 1989, and then 1.98 percent from 1989 to 2007. Then between 2007 and 2010, median wealth plunged by a staggering 43.9 percent! Median wealth rebounded somewhat from 2010 to 2016, climbing by 17.1 percent, and again from 2016 to 2019, by 21.2 percent, though it was still down 20.4 percent from its peak in 2007.

\section{[Table 2 and Figure 9 about here]}

Mean net worth also grew vigorously from 1983 to 1989, at an annual rate of 2.52 percent per year, about double the growth rate of median wealth. Over years 1989 to 2007, the growth rate of mean wealth accelerated to 3.24 percent per year. Mean wealth in 2007 was more than double its value in 1983. Another point of note is that mean wealth grew much faster than the median from 1983 to 2007, indicative of widening inequality of wealth.

The Great Recession also saw an absolute decline in mean household wealth. However, whereas median wealth plunged by 43.9 percent between 2007 and 2010, mean wealth fell by (only) 16.1 percent. However, here, too, the relatively faster growth in mean wealth than median wealth (that is, the latter's more moderate decline) was coincident with rising wealth inequality. Mean wealth then grew by 27.9 percent from 2010 to 2016 and was 7.3 percent above its previous 2007 peak. This was followed by almost no change from 2016 to 2019.

\footnotetext{
${ }^{10}$ It should be noted that the 1983 and 1989 SCF data files were aligned to national balance sheet totals in order to provide consistency in the household wealth estimates, since they each use somewhat different sampling frames and methodologies. Estimates for 1992 onward are based on the standard SCF data. My baseline estimates, as note above, also exclude vehicles. Moreover, my calculations are based on the "public use" samples provided by the Federal Reserve Board, which are to some degree different from the internal files maintained by the Federal Reserve Board. As a result, my figures on mean and median net worth, as well as on wealth inequality, will in general be at a slight variance from the "standard" estimates provided by the Federal Reserve Board which include the value of vehicles in their statistics (see, for example, Kennickell and Woodburn, 1999, and Bricker et. al., 2016b).
} 
The figures in Table 3 show that wealth inequality, after rising from 1983 to 1989, remained virtually unchanged from 1989 to 2007 according to the Gini coefficient (also see Figure 7). Over these years, the share of the top percentile actually declined a bit, from 35.2 to 34.6 percent, though this was more than compensated for by an increase in the share of the next four percentiles. As a result, the share of the top five percent increased from 58.0 percent in 1989 to 61.8 percent in 2007 , and the share of the top quintile rose from 83.0 to 85.0 percent. The share of the fourth and middle quintiles each declined by about a percentage point, while that of the bottom 20 percent increased by 0.2 percentage point. Overall, the Gini coefficient saw a very small rise, from 0.828 in 1989 to 0.834 in 2007.

\section{[Table 3 about here]}

The years 2007 to 2010 saw a sharp elevation in wealth inequality, with the Gini coefficient rising from 0.834 to 0.866 . Interestingly, the share of the top percentile showed only a half percentage point gain. Most of the rise in wealth share took place in the remainder of the top quintile, and overall the share of wealth held by the top quintile climbed by 3.6 percentage points. The shares of the other quintiles, correspondingly, dropped, with the share of the second quintile falling by 0.4 percentage points and that of the bottom quintile by 0.7 percentage points.

From 2010 to 2016 there was a small rise in the Gini coefficient, from 0.866 to 0.877 . The share of the top one percent experienced a huge increase of 4.5 percentage points but the share of the next 19 percent went down, so that the wealth share of the top quintile dropped slightly, by 0.3 percentage points. The wealth of the fourth quintile also lost 1.3 percent, that of the middle quintile fell 0.3 percent, but that of the bottom forty percent gained 0.4 percent. From 2016 to 2019, the Gini coefficient dropped from 0.877 to 0.869 . The share of the top percentile fell by 1.4 percentage points and that of the top quintile by 1.0 percentage points and the wealth share of the other quintiles rose. In constant dollar terms, the net worth of the top one percent actually declined by 1.9 percent over those years.

\subsection{Overall Portfolio Composition}

Table 4 presents the "consolidated" wealth accounts for all households in which stocks and bonds owned indirectly through defined contribution plans like 401(k)s and IRAs, mutual funds and trust funds are allocated to their constituent elements. The results show a rather different picture than the standard portfolio composition. In 2019, as in the standard accounts, 
owner-occupied housing was the most important household asset, accounting for 26.9 percent of total assets (also see Figure 10). However, net home equity -- the value of the house minus any outstanding mortgage -- amounted to only 17.7 percent of total assets. Real estate, other than owner-occupied housing, comprised 9.4 percent, and business equity another 20.0 percent. Demand deposits, time deposits, money market funds, CDs, and the cash surrender value of life insurance (collectively, “liquid assets”) made up 6.8 percent

\section{[Table 4 and Figure 10 about here]}

The major difference is the share of bonds and stocks. Bonds and other financial securities amounted to 12.9 percent in the consolidated accounts, compared to 0.9 percent in the standard accounts. Corporate stocks now comprised 22.6 percent, compared to 15.5 percent for stocks plus mutual funds in the standard accounts. Debt as a proportion of gross assets was 12.9 percent, and the debt to net worth ratio was 14.9 percent, while the debt-income ratio was 104.0 percent.

There were some notable changes in the composition of household wealth over years 1983 to 2019. First, the share of housing wealth in total assets jumped from around 30 percent in 1983-2001 to a peak value of 33.5 percent in 2004 but then declined to 26.9 percent in 2019. Two factors explain this movement. The first is the trend in the homeownership rate, which rose from 63.4 percent in 1983 to a top value of 69.1 percent in 2004 and then fell off to 64.9 percent in 2019. The second is that the median house price for existing one-family homes rose by 16.9 percent between 2001 and 2004 and then inched up by 3.9 percent from 2004 to 2019. A second and related trend is that net home equity, after falling almost continuously from 23.8 percent of total assets in 1983 to 18.2 percent in 1998, picked up to 21.8 percent in 2004 but then fell to 17.7 percent in 2019. The difference between the two series (gross versus net) is attributable to the changing magnitude of mortgage debt on homeowner's property, which increased from 20.9 percent in 1983 to 37.0 percent in 1998 but then fell back to 34.0 percent in 2019.

A third change is that stocks directly and indirectly owned as a share of total assets more than doubled from 11.3 percent in 1983 to a peak of 24.5 percent in 2001, but then declined to 22.6 percent in 2019. The rise during the 1990s reflected the bull market in corporate equities as well as increased stock ownership, while the decline in the 2000s was a result of the sluggish stock market as well as a drop in stock ownership. The increase from 2010 to 2019 reflected the 
recovery of the stock market and increases in stock ownership. A fourth is that securities directly and indirectly owned rose almost continuously over time from 6.0 percent of total assets in 1983 to 13.9 percent in 2016 but then fell off to 12.9 percent in 2019.

Fifth, overall relative indebtedness first increased, with the debt to net worth ratio climbing from 15.1 percent in 1983 to 20.6 percent in 2010, and then tumbled to 14.9 percent in 2019. Likewise, the debt-income ratio surged almost continuously over time from 68.4 percent in 1983 to a peak of 127.0 percent in 2010 but then dropped off sharply to 104.0 percent in 2019. If mortgage debt on principal residence is excluded, then the ratio of other debt to total assets actually fell off over time from 6.8 percent in 1983 to 3.8 percent in 2019.

The large rise in relative indebtedness among all households between 2007 and 2010 could be due to a rise in the absolute level of debt and/or a fall-off in net worth and income. As shown in Table 1, both mean net worth and mean income fell over the three years. There was also a slight contraction of debt in constant dollars, with mortgage debt declining by 5.0 percent, other debt by 2.6 percent, and total debt by 4.4 percent. Thus, the steep rise in the debt-net worth and the debt-income ratios over the three years was entirely due to the reduction in wealth and income. In contrast, from 2010 to 2019, relative indebtedness declined sharply. The main reason was sizeable gains in both mean wealth and mean income, which was reinforced by a 6.2 percent reduction in average household debt.

\section{$\underline{6.2 \text { Portfolio composition by wealth class }}$}

The tabulation in Table 4 provides a picture of the average holdings of all families in the economy, but there are marked class differences in how middle-class families and the rich invest their wealth. As shown in Table 5, the largest asset in value terms among the richest one percent of households (as ranked by wealth) was business equity, which comprised 37.9 percent of their total assets in 2019 (also see Figure 11). Stocks were second, at 25.8 percent, followed by securities and then other real estate. Housing accounted for only 8.9 percent of their assets and liquid assets 5.0 percent. Their ratio of debt to net worth was only 2.4 percent, their ratio of debt to income was 45.3 percent, and the ratio of mortgage debt to house value was 15.3 percent.

\section{[Table 5 and Figure 11 about here]}


Among the next richest 19 percent of U.S. households, housing comprised 25.9 percent of their total assets (net home equity was 18.9 percent) and liquid assets 7.5 percent. Investment assets -- real estate, business equity, stocks, and bonds - made up 65.5 percent of which 25.4 percent was in the form of stocks directly or indirectly owned. Debt amounted to 10.3 percent of their net worth and 95.9 percent of their income, and the ratio of mortgage debt to house value was 27.0 percent.

In contrast, 64.3 percent of the assets of the middle three wealth quintiles of households was invested in their own home in 2019. However, home equity amounted to only over a third of total assets, a reflection of their large mortgage debt. Another 8.3 percent went into monetary savings of one form or another. The remainder was split among non-home real estate, business equity, and financial securities and corporate stock. Stocks directly or indirectly owned amounted to only 8.6 percent of their total assets. The ratio of debt to net worth was 57.5 percent, and their debt-income ratio was 122.0 percent, both much higher than that of the top quintile. Finally, their mortgage debt amounted to 44.5 percent of the value of their principal residences.

Almost all households among the top 20 percent of wealth holders owned their own home, in comparison to 70.5 percent of households in the middle three quintiles. Three-quarters of very rich households (in the top percentile) owned some other form of real estate, compared to 44.8 percent of rich households (those in the next 19 percent of the distribution) and only 12.6 percent of households in the middle 60 percent. A stunning 71.7 percent of the very rich reported owning their own business. The comparable figures were 29.6 percent among the rich and only 9.0 percent of the middle class.

Among the very rich, 91.1 percent held corporate stock, mutual funds, financial securities or a trust fund, in comparison to 61.9 percent of the rich and 16.8 percent of the middle class. Almost all of the very rich reported owning stock either directly or indirectly, compared to 88.8 percent of the rich and 45.9 percent of the middle. If we exclude small holdings of stock, then the ownership rates drop off sharply among the middle three quintiles, from 45.9 percent to 34.6 percent for stocks worth $\$ 5,000$ or more and to 28.7 percent for stocks worth $\$ 10,000$ or more.

More details are provided in Table 6 on the evolution of wealth for the middle three wealth quintiles. Perhaps, the most striking development is the homeownership rate, which after rising almost continuously over time from 71.6 percent in 1983 to 78.2 percent in 2007, plunged 
to 67.0 percent in 2016. However, there was a notable pick-up to 70.5 percent in 2019. This trend was more pronounced than that among all households, among whom the homeownership rate dropped from 69.1 percent in 2004 to 63.7 percent in 2016 followed by a modest rebound to 64.9 percent in 2019. A similar trend is evident for the share of homes in total assets, which remained virtually unchanged from 1983 to 2001 but then rose sharply in 2007. This increase was largely a result of rising house prices and gains in the homeownership rate. The share then declined from 2007 through 2016 as the homeownership rate plummeted but then bounced back in 2019 .

\section{[Table 6 about here]}

The share of all stocks in total assets mushroomed from 2.4 percent in 1983 to 12.6 percent in 2001 but and then fell off to 8.6 percent in 2019. The stock ownership rate among the middle class also shot up sharply from 16.5 percent in 1983 to 51.1 percent in 2001, when it peaked. It then declined steeply to 41.4 percent in 2016 but recovered to 45.9 percent in 2019. In similar fashion, the share of middle class households owning either corporate stock, financial securities, mutual funds or a personal trust rose from 21.6 percent in 1983 to 27.5 percent in 2001, plunged to 15.3 percent in 2016, and then bounced back a bit to 16.8 percent in 2019. The share of securities directly or indirectly owned in total assets ballooned from 1.9 percent in 1983 to 10.8 percent in 2016 and then fell off to 9.3 percent in 2019. Liquid assets as a share of total assets declined by 13.1 percentage points from 21.4 percent in 1983 to 8.3 percent in 2019 . These trends more or less parallel those of all households.

The debt to net worth ratio rose from 37.4 to 57.5 percent and the debt-income ratio almost doubled over this period. It is of note that the source of rising debt was mortgage debt on the principal residence. Other debt as a fraction of total assets actually declined over these years.

A similar tabulation is shown for the top one percent in Table 7. Other real estate as a share of total assets trended downward from 19.9 percent in 1983 to 9.6 percent in 2019 while that of unincorporated business trended upward from 32.1 to 37.9 percent. As for all households, the share of liquid assets in total assets fell over these years while that of stocks and securities directly or indirectly owned rose. The debt to net worth ratio fell by over half for the top one percent from 1983 and 2019, and the debt-income ratio by almost half. Asset ownership rates are much higher for the top percentile than the middle class, particularly for businesses, non-home real estate, stocks, and other financial assets. 


\section{[Table 7 about here]}

\section{Decomposition Results by Wealth Class}

I begin with the basic relationship:

(1) $\Delta \mathrm{W}_{\mathrm{T}} \equiv \mathrm{W}_{\mathrm{t}}-\mathrm{W}_{\mathrm{t}-1}=\sum_{\mathrm{i}} \mathrm{r}_{\mathrm{TT}} \mathrm{Ai}_{\mathrm{T}}+\mathrm{S}_{\mathrm{T}}+\mathrm{G}_{\mathrm{t}}$

where $\mathrm{W}_{\mathrm{t}}=$ mean net worth (in constant dollars) at time $\mathrm{t} ; \Delta \mathrm{W}_{\mathrm{T}}=$ change in mean wealth over period $\mathrm{T}$ from year $\mathrm{t}-1$ to $\mathrm{t}$; $\mathrm{W}_{\mathrm{T}}=$ average wealth over period $\mathrm{T}$; $\mathrm{r}_{\mathrm{iT}}=$ the average real rate of return on asset i over period $\mathrm{T}$; $\mathrm{A}_{\mathrm{iT}}=$ average value of asset $\mathrm{i}$ over period $\mathrm{T} ; \mathrm{S}_{\mathrm{T}}=$ average household savings (in constant dollars) excluding capital gains and property income over period $\mathrm{T} ;{ }^{11}$ and $\mathrm{G}_{\mathrm{T}}=$ average net inheritances and gifts (in constant dollars) over period T. With regard to variable GT, the SCF contains questions on (inter-vivos) gifts and inheritances received as well as gifts given to others and donations made to charitable organizations.

On the basis of equation (1), the change in wealth can be decomposed into capital revaluation (existing wealth multiplied by the rate of return), savings, and net intergenerational transfers. The analysis is divided into six sub-periods: 1983-1989, 1989-2001, 2001-2007, 20072010, 2010-2016, and 2016-2019. The same decomposition can be used for the wealth of each wealth group.

Table 8 assesses the effects of actual changes in the interest rate and inflation rate on wealth by wealth group and overall wealth inequality. Again, it should be noted that the asset price changes used in the analysis are those emanating only from these two monetary policy parameters. I use "Fed policy" as a shorthand for the combined effects of interest rate and inflation rate changes on the household balance sheet. ${ }^{12}$ For this analysis, $\mathrm{r}_{\mathrm{iT}}$ is based solely on the asset (and debt) price changes associated with Fed policy - that is, how it affects stock prices, bond values, business value, home prices, the value of non-home real estate and liquid assets,

\footnotetext{
${ }^{11}$ Though the standard SCF income measure includes realized capital gains as well as property income, these two components are excluded from $S_{\mathrm{T}}$ since they are already captured in the term riT.

${ }^{12}$ This is not to say that that the Federal Reserve Bank completely controls the 10-year bond rate and the inflation rate but rather influences their movements over time. The effects of quantitative easing $(\mathrm{QE})$ are captured indirectly in terms of its effect on bond yields, particularly long-term bonds. QE effectively injects new money into the money supply by buying up government issued bonds. This policy increases the demand for bonds and raises bond prices and thereby lowers bond yields.
} 
and household debt. For the base case, I use the 10-year real bond rate for a 10-year period based on constant maturity Treasury securities and a 30-year fixed rate mortgage with a 20 percent down-payment and monthly payments.

Panel A shows results for overall mean net worth. Over the full 1983-2019 period, mean net worth rose by 127.6 percent. Asset price changes due to Fed actions accounted for 72.6 percent of the wealth advance. Home price gains emanating from declining mortgage rates by themselves explained 36.5 percent of the rise. Debt deflation resulting from the rise in the CPIU-RS was second in importance, at 18.6 percent, followed by non-home real estate, at 14.6 percent, bonds at 6.3 percent, and businesses at 5.2 percent. Stock price gains accounted for a mere 4.9 percent of the overall rise in mean net worth. Liquid assets contributed -13.5 percent.

\section{[Table 8 about here]}

Results differ by sub-period. Over 1983-1989, Fed policy accounted for 104.9 percent of the advance in mean wealth, led by house and non-home real estate price gains. Over 1989-2001, it explained 45.7 percent and over 2001-2007, 27.4 percent. Over the Great Recession, Fed policy accounted for 71.9 percent of the decline in mean wealth, largely due to the collapse in home prices. In 2010-2016, Fed policy explained 37.9 percent of the advance and in 2016-2019 57.9 percent, more than all of it due to home prices and debt devaluation. In this case, changes in stock, business, and bond prices had negative effects.

The story is quite different for median wealth. In this case, asset price changes would have led to a 204.9 percent gain in median wealth over 1983-2019, compared to the actual advance of 23.4 percent. The rise in home prices resulting from the drop in the mortgage interest rate would by itself have increased median wealth by 131.2 percent and the devaluation of debt by 75.9 percent. The devaluation of liquid assets subtracted 26.7 percent. The other components of wealth were unimportant.

Over 1983-1989, asset price changes would have led to a 28.1 percent boost in median wealth, primarily due to house price gains, compared to the actual 8.7 percent rise; over 19892001, a 45.0 percent increase in the median, primarily from house prices and secondarily from debt deflation, compared to the actual 19.9 percent rise; and in 2001-2007, it accounted for 74.9 percent of the increase in median wealth, primarily due to debt devaluation and secondarily to house price gains. Over the Great Recession, while median wealth plunged by 43.9 percent, Fed policy should have boosted it by 26.6 percent, almost entirely due to house price gains. In 2010- 
2016, Fed policy would have led to a 22.5 percent rise in the median, primarily from house prices and secondarily from debt deflation, compared to the actual 17.1 percent. In 2016-2019, in contrast, Fed policy accounted for 28.6 of the advance in median wealth, primarily due to debt devaluation and secondarily to house price gains.

In contrast to median wealth, asset price changes resulting from Fed policy accounted for only about a third of the 157.2 percent increase of the mean wealth of the top percentile over years 1983-2019. The main contributor to this gain was non-home real estate, followed by homes, businesses, bonds, and then stocks. Over 1983-1989, Fed policy explained about two thirds of the gain, led by non-home real estate and then businesses; over 1989-2001, about a third of the increase, primarily due to non-home real estate; and over 2001-2007, only 9.6 percent of the wealth growth. Over the Great Recession, the mean wealth of the top percentile declined by 15.5 percent. Asset prices associated with Fed policy would have led to a 5.2 percent gain, largely due to non-home real estate and homes. In 2010-2016, their mean wealth grew by 45.4 percent but Fed policy explained only 14.6 percent of the gain. Over the most recent period, 2016-2019, their mean wealth fell by 1.9 percent. Fed policy collectively explained 21.7 percent of this decline due to the offsetting positive effects of home and non-home real estate prices and negative effects on stock, business, liquid assets and bond prices.

For the inequality analysis, I first consider changes over time in the ratio of mean wealth of the top one percent to the median. I can then determine what portion of the change in this ratio is due to asset price changes emanating from Fed policy. On the basis of this measure, wealth inequality increased in each of the first five periods but declined in the last, 2016-2019 (first row of Panel D). ${ }^{13}$ The next row shows what happens to the wealth ratio when asset price changes resulting from Fed actions only is added to initial wealth. The upshot is that Fed policy uniformly reduces the wealth ratio and the effect is quite large.

In the 1983-1989 period, Fed policy would have lowered the wealth ratio by 14.1 from 131.4 to 117.3 or by 11.5 percent (14.1/131.4). This is due to the fact that the boost to home prices and deflation of real debt were greater in relative terms than the stimulus to stock, business, and bond values. The wealth ratio rose, instead, by 15.1 or by 11.5 percent (15.1/131.4). Results are similar for the next four periods. In 1989-2001, Fed policy reduced the

\footnotetext{
${ }^{13}$ Note that this time trend is rather different from that of the overall wealth Gini coefficient.
} 
wealth ratio by 21.4 percent, compared to its actual increase of 17.9 percent; in 2001-2007, the respective figures are 10.4 percent reduction compared to a 4.6 percent increase; in 2007-2010, a 16.9 percent decrease in comparison to a 50.6 percent augmentation; and in 2010-2016, a 13.0 percent diminution in contrast to a 24.2 percent enhancement. The period 2016-2019 is different. In this case, the actual wealth ratio fell by 6.6 percent, with Fed policy explaining about a third of the decline.

Panel E shows a similar tabulation based on the actual wealth Gini coefficient. Almost the same pattern unfolds. There is a sizeable reduction in inequality over the full 1983-2019 period, with the Gini coefficient declining by 0.045 . The Gini coefficient decreased in all six sub-periods. The drop was particularly strong over years 1989-2001.

\section{The racial and ethnic wealth gap}

Has the general decline in interest rates and moderation in inflation lowered or raised the racial and ethnic wealth gap? I expect that these two effects will lower the gap since Black and (non-Hispanic) white households hold a higher proportion of their assets in homes and a much lower share in financial assets and also have a much higher debt-net worth ratio.

Striking differences are found in the wealth holdings of different racial and ethnic groups. In Figure 12, households are divided into three groups: (i) non-Hispanic whites, (ii) nonHispanic African-Americans, and (iii) Hispanics (also see Table 9 below). ${ }^{14}$ The ratio of mean wealth holdings between Black and white households was 0.19 in 1983 and again in 2007. ${ }^{15}$ The picture is different for Hispanics. In 2007, the ratio of mean net worth was 0.26 compared to a ratio of 0.19 between Blacks and whites. The ratio of mean net worth between Hispanic and white households climbed from 0.16 in 1983 to 0.26 percent in 2007, compared to no change in the racial wealth gap.

\section{[Figure 12 about here]}

The racial/ethnic picture changed radically by 2010, with the ratio of mean net worth between black and white households dropping from 0.19 to 0.14 . The proximate causes were the higher leverage of black households and their higher share of housing wealth in gross assets (see

\footnotetext{
14 The residual group, American Indians and Asians, is excluded here because of its small sample size in most years.

${ }^{15}$ Ratios of median wealth were even lower, at 0.07 in 1983 and 0.06 in 2007.
} 
Table 9). The Great Recession hit Hispanic households even harder than Black households, with the mean net worth in constant dollars of Hispanics falling almost in half, and the ratio of this to the mean net worth of white households plummeting from 0.26 to 0.15 . The same factors were responsible as in the case of Black households.

Was there any improvement after 2010? Between 2010 and 2016 the mean net worth of Black households was up by 31.8 percent but there was no change relative to white households. In years 2016 to 2019 the mean net worth of Black households declined sharply, by 5.9 percent, though relative to white households, Black mean wealth remained unchanged. However, all in all, Black mean net worth was still well below, by 16.5 percent, its 2007 peak value. From 2010 to 2016, the mean net worth of Hispanic households shot up by 61.6 percent and their position relative to white households advanced from a ratio of 0.15 to 0.19 . Years 2016 to 2019 saw their mean net worth down slightly but unchanged relative to white families. However, like Black wealth, Hispanic mean net worth in 2019 was still well below its 2007 peak value and almost to the same degree.

Table 9 shows the portfolio composition by racial/ethnic group in 2019. Again, there are stark differences between whites and the two minority groups. The share of housing in total assets is almost double among the two minority groups as among white households, while the share of business equity and stock directly or indirectly owned is much lower. Interestingly, the share of financial securities is about the same for white and Black families but lower among Hispanics. The debt-asset ratio is considerably higher among the two minorities for both mortgage and non-mortgage debt and overall. These differences will play a critical role in analyzing the effect of Fed policy on the wealth gap.

\section{[Table 9 about here]}

Table 10 assesses the effects of changes in the interest rate and inflation rate on the racial and ethnic wealth gap. Again, it should be stressed that the asset price changes used in the analysis are those emanating only from these two monetary policy parameters. Panel A shows results for mean net worth among white households. The results are not too surprisingly quite similar to those for all households. Over the full 1983-2019 period, their mean net worth rose by 149.0 percent, with asset price changes accounting for 64.9 percent of the advance. Home price gains explained 30.7 percent, debt deflation another 14.4 percent, non-home real estate 11.7 
percent, and bonds 9.1 percent. Stock prices accounted for only 4.2 percent and liquid assets reduced it by 9.8 percent

\section{[Table 10 about here]}

Results differ by period. Over 1983-1989, Fed policy accounted for 93.5 percent of the wealth gain, led by house prices. Over 1989-2001, it explained 46.1 percent and over 2001-2007, 28.1 percent. Over the Great Recession, Fed policy accounted for almost all of the decline in mean wealth, primarily due to the collapse in home prices and secondarily to that in non-home real estate values. In 2010-2016, Fed policy explained 35.3 percent of the advance. In 2016-2019 their mean wealth declined by 0.8 percent. Fed policy would have raised it by 0.6 percent, more than all of it due to home prices and debt devaluation. In this case, changes in stock, business, liquid assets, and bond prices had a negative effect.

The story is quite different for the mean net worth of Black households. In this case, asset price changes would have led to a 193.7 percent gain in their wealth over 1983-2019, compared to the actual advance of 81.0 percent. The rise in home prices resulting from the drop in the mortgage interest rate would by itself have more than doubled their wealth, while the devaluation of their debt would have increased it by two thirds. The other components of wealth were less important.

Over 1983-1989, asset price changes would have led to a 27.4 percent gain in their wealth, primarily due to house price gains, compared to the actual 7.0 percent growth; over 1989-2001, a 43.9 percent rise in their net worth, primarily from house prices and secondarily from debt deflation, compared to the actual 28.4 percent growth; and in 2001-2007, it accounted for about one quarter of the wealth increase, primarily due to debt devaluation and secondarily to house price gains. Over the Great Recession, while their net worth went down by a third, Fed policy should have boosted it by 24.1 percent, almost entirely due to house price gains. In 20102016, Fed policy would have led to a 21.2 percent rise, primarily from house prices and secondarily from debt deflation, compared to the actual 31.8 percent. In 2016-2019, in contrast, while their net worth decreased by 5.9 percent, Fed policy would have led to a 5.1 percent gain, primarily due to debt devaluation and secondarily to house price gains.

Results are similar for Hispanic households as for Black households. Asset price changes would have led to a 212.1 percent growth in their wealth over 1983-2019, slightly more than the actual gain of 187.2 percent. Gains in home prices by themselves would have more than doubled 
their wealth, while the devaluation of their debt would have increased it by almost three quarters. The other components of wealth were again not as important.

Over 1983-1989, asset price changes would have led to a 26.6 percent boost in their wealth, primarily due to house price gains and secondarily to debt reduction, compared to the actual 21.6 percent advance; over 1989-2001, a 49.2 percent rise, again primarily from house prices and secondarily from debt deflation, compared to the actual 57.8 percent growth; and in 2001-2007, it would have raised their wealth by 13.3 percent, primarily due to debt devaluation and secondarily from house price increases. Over the Great Recession, while their net worth collapsed by almost half, Fed policy should have lifted it by a quarter, primarily due to house price gains. In 2010-2016, Fed policy would have led to a 22.5 percent increase, primarily from house prices and secondarily from debt deflation, compared to the actual 61.6 percent. In 20162019, while their net worth decreased by 1.8 percent, Fed policy would have caused a 4.9 percent rise, primarily due to debt devaluation and secondarily to house price advances.

The ratio of mean wealth between Black and white households seesawed over years 1983 to 2019 (Panel D). However, Fed policy would have raised the ratio in each of the six time periods and over the full 1983-2019 time span. In the 1983-1989 period, Fed policy lifted the wealth ratio by 0.014 or 7.2 percent, compared to an actual decline of 0.021 . This is mainly because the boost in home prices and devaluation of real debt were greater in relative terms than the stimulus to stock, business, and bond values. In 1989-2001, Fed policy increased the wealth ratio by 16.5 percent, compared to an actual decline of 15.0 percent; in 2001-2007, the respective figures are a 7.5 percent rise compared to a 32.1 percent increase; in 2007-2010, a 12.1 percent lift in comparison to a 23.7 percent reduction; in 2010-2016, a 9.2 percent rise in contrast to a 0.4 percent enhancement; and in 2016-2019, 4.5 percent increase in comparison to a 5.2 percent decrease. Over the full 1983-2019, the racial wealth ratio fell by 0.051 or by 27.3 percent. However, Fed policy raised the wealth ratio by 0.093 or 49.4 percent. That is to say, the wealth ratio would have been 0.230 in 2019 instead of the actual 0.137 .

The pattern is different for the Hispanic/white wealth ratio. In this case, the actual ratio rose in all time periods except 2007-2010 and 2016-2019, while Fed policy would have raised the ratio in each of the six time periods except 1983-1989, and over the full 1983-2019 time span. In 1983-1989, Fed actions reduced the wealth ratio by 0.001 or 0.8 percent, compared to an actual increase of 0.002 or 1.2 percent. In 1989-2001, asset price changes raised the wealth 
ratio by 19.0 percent, compared to an actual rise of 4.5 percent; in 2001-2007, the respective figures are a 24.6 percent rise compared to a 51.9 percent augmentation; in 2007-2010, a 40.9 percent boost in comparison to a 41.1 percent decrease; in 2010-2016, a 17.0 percent expansion in contrast to a 23.2 percent growth; and in 2016-2019, 28.1 percent elevation in comparison to virtually no change. Over the full time span 1983-2019, the actual racial wealth ratio was up by 0.025 or 15.3 percent. Fed policy would have enhanced the wealth ratio by 0.070 or 42.9 percent. That is to say, the wealth ratio would have been 0.230 in 2019 instead of the actual 0.137.

\section{Wealth by Age Group}

Another issue is whether younger or older households benefited more from the secular decline in interest and inflation rates. I expect that younger households do better since, like minorities, they have a higher proportion of their assets in homes and a lower share in financial assets and also have a much higher level of relative indebtedness.

Table 11 shows the actual evolution of relative wealth by age group (also see Figure 13). Perhaps, the most notable development is the decline in the relative (and absolute) wealth of younger households. The relative wealth of the youngest age group, under 35 years of age, expanded from 21 percent of the overall mean in 1983 to 29 percent in 1989 but then collapsed to 17 percent in 2007. In 2007, the mean wealth of the youngest age group was $\$ 112,700$ (in 2019 dollars), which was only slightly more than the mean wealth of this age group in 1989 $(\$ 105,600)$.

\section{[Table 11 and Figure 13 about here]}

The mean net worth of the next youngest age group, 35-44, relative to the overall mean tumbled from 0.71 in 1983 to 0.58 in 2007, with most of the relative decline taking place between 2004 and 2007. The relative wealth of the next youngest age group, 45-54, also declined rather steadily over time, from 1.53 in 1983 to 1.19 in 2007, while that of age group 55-64 generally gained over time from 1.67 in 1983 to 1.69 in 2007. The relative net worth of age group 65-74 dipped somewhat from 1.93 in 1983 to 1.86 in 2007, while that of the oldest age group went from 5 percent above the mean in 1983 to 16 percent above in 2007.

Changes in relative wealth were equally dramatic from 2007 to 2019. The relative wealth of the under 35 age group continued to plummet from 0.17 to 0.08 and that of age group 35-44 from 0.58 to 0.40 in 2016, though it did pick up to 0.57 in 2019. The mean net worth of age 
group 45-54 slipped somewhat from 1.19 to 1.11. In actual (2019 dollar) terms, the average wealth of the youngest age group collapsed almost in half, from $\$ 112,700$ in 2007 to $\$ 61,300$ in 2019, its second lowest point over the 36-year period (the lowest occurred in 1995), while the relative wealth of age group 35-44 shrank from \$381,700 in 2007 to \$283,100 in 2016, though it did bounce back to $\$ 415,700$ in 2019 . The relative net worth of age group 55-64 dropped from 1.69 in 2007 to 1.59 in 2019 while in absolute terms there was little change. The same pattern held for age group 65-74. In contrast, the relative wealth of the oldest age group, age 75 and over, rose 1.16 to 1.30 , and was up by 22.3 percent in constant dollar terms.

Changes in the relative wealth position of different age groups depend in large measure on relative asset price movements and differences in asset composition. The latter are highlighted in Table 12 for the year 2019 based on consolidated household accounts. Homes comprised over half the value of total assets for age group 35 and under, and its share of total assets fell off with age to about a quarter for age group 75 and over. Liquid assets as a share of total assets was higher for the youngest and oldest age groups, at around nine percent, than the other age groups, at around six to seven percent. This pattern partially reflects the relative financial conservativeness of older (and younger) people. Corporate stock and financial securities show a fairly steady rise with age - for the former from a 6.0 percent share for the youngest group to a 13.7 percent share for the oldest and for the latter from 8.4 to 28.0 percent. Business equity was more important in the portfolios of age groups 35-44, 45-54, and 55-64 than in the youngest and two oldest age groups. The share of non-home real estate in total assets was relatively flat across age groups except for the youngest group, for whom it was particularly low. There was a pronounced fall off of debt with age. The debt-asset ratio declined continuously with age from 56.7 percent for the youngest group to 4.6 percent for the oldest.

\section{[Table 12 about here]}

Younger households were thus more heavily invested in homes and more heavily in debt whereas the portfolio of older households was more heavily skewed to financial assets, particularly corporate stock. As a result, younger households benefit in relative terms when housing prices rise and inflation is strong while older households benefit from rising stock prices. Changes in the relative net worth position of age groups over years 1983 to 2019 were to a large extent due to differences in portfolio composition and relative asset price movements. As 
with black and Hispanic households, the higher leverage of younger age groups make them vulnerable when asset prices, particularly housing prices, decline.

Table 13 examines how actual changes in the interest rate and inflation rate affect mean household wealth by ae group. The asset price changes used here are those emanating only from these two parameters. Let us consider the full1983-2019 period first. The mean wealth of the under 35 age group relative to overall mean wealth declined by 0.067 . However, asset price changes would have led to a 0.107 advance. Almost all of the relative gain is attributable to a greater house price rise and larger debt devaluation among this age group than among all households. The increase in the value of non-home real estate also made a positive contribution but this was offset by the decrease in the real value of liquid assets.

\section{[Table 13 about here]}

The relative wealth of age group 35-44 fell by 0.051 but asset price changes would have boosted it by 0.062 . This was primarily due to relative advances in house prices and secondarily due to greater debt devaluation. In contrast, asset price movements made a negative contribution to the mean wealth of older households relative to all households and the effect increased across age groups. Asset price variation lowered the relative net worth of age group 35-54 by 0.015, that of age group 55-64 by 0.121, that of age group 65-74 by 0153, and that of age group 75 and over by 0.156 . The reasons are, as discussed above, that the share of housing in total assets falls off with age (except for the oldest age group), so that the gains from rising house prices are progressively less than average, and that relative indebtedness declines monotonically with age, so that the lift in net worth from debt devaluation relative to overall net worth also declines with age.

Results by sub-period also follow this pattern with the exception of one age group. Asset price changes raise the relative net worth of age group 35 and under and that of age group 35-44 in all six sub-periods. However, they also increased the relative wealth of age group 45-54 in all six sub-periods whereas they lowered it (slightly) over the full 1983-2019 stretch. Asset price movements lowered the relative wealth of age groups 55-64, 65-74, and 75 and over in all six sub-periods as well as over the full 1983-2019 time span.

\section{Variants}


I next conduct sensitivity tests to see how the results of Table 8 change with varying assumptions about price changes in asset values. Results on asset price movements are shown in Table 14. Here I show the percentage change in real asset values over each period instead of the annualized percentage change. The base case for bond values uses the 10-year Treasury bill rate for a 10-year period. Its value increased by 66.3 percent over the full 1983-2019 period. However, on the basis of the 20-year Treasury bond rate for a 20-year period, the percentage rise in bond value over the period more than doubled to 133.3 percent. The reason is evident from equation 3 , the formula for bond values, where $\mathrm{P}_{\mathrm{b}}$ rises with the number of periods, $\mathrm{T}$. Actual real yields on 20-year bonds are also uniformly higher than those on 10-year bonds (with one exception, 1989) but the differences were relatively small, with a maximum value of 1.00 percentage points in 2008. Using the 30-year bond rate for a 30 -year period raises the percentage gain over the 1983-2019 period to 140.7 percent, not much more than the 20-year bond for a 20year period. Yields on 30-year bonds were higher than those on 10-year bonds in all years except three. However, differences were again small, with a maximum of 1.13 percentage points in 2011. The difference in percentage gains was again primarily due to the longer holding period for the 30-year bond relative to the 10-year bond. ${ }^{16}$

Percentage gains in bond values were also notably higher for the 20-year and 30-year bonds than the 10-year bonds in each of the sub-periods as well with the exception of the 20072010 period. The greater returns to the 20-year and 30-year bonds relative to the 10-year bonds will benefit the rich relative to the middle class since the former hold a higher share of their assets in bonds than the latter.

The pattern of results is very similar for the calculation of the present value of future profits. On the basis of a 10-year bond rate for 10 years, the gain over the 1983-2019 period was 30.3 percent. The use of the 20 -year bond for 20 years more than doubled this to 67.7 percent. Here again the primary reason for the difference is the longer recoupment period for the latter. This is evident from equation 1 where pa rises with T, the number of periods. Employing a 30year bond rate for 30 years further enhances the percentage gain to 101.0 percent, a significant rise. Once again the percentage gain in the present value of future profits was greater in each of

\footnotetext{
${ }^{16}$ Differences in percentage gains over a period between the 30-year and 20-year Treasury bond are small because, as indicated in equation 3 , the term $\mathrm{C} /(1+\mathrm{i})^{\mathrm{t}}$ becomes very small for $\mathrm{t}>20$.
} 
the sub-periods as well with the exception of 2007-2010. The use of a longer recoupment period in this calculation will benefit the rich relative to the middle class since the former hold a higher share of their assets in stocks and businesses than the latter.

Imputed home price gains were considerably smaller on the basis of a 10-year mortgage period than a 30-year mortgage period - 45.4 percent versus 137.4 percent over 1983-2019. The explanation is as follows. The difference in the average interest charged between 10-year and 30year mortgages was relatively small, varying from a high of 0.22 percent in 2006 to a low of -1.50 percent in 1984. Interestingly, the differences were mainly negative until 2004 and mainly positive after that. Monthly payments are not surprisingly uniformly higher on the basis of a 10year mortgage than a 30-year one. However, more importantly, the difference in monthly payments grew over time from $\$ 343.23$ in 1983 to $\$ 535.88$ in 2019. As a result, whereas the reduction in monthly payments over these years was 31.2 percent for the former, it was 62.0 percent for the latter. This then translates into a higher percentage increase in home prices on the basis of a 30-year than a 10-year mortgage. This relationship held in every sub-period except 2016-2019. A longer-period mortgage will benefit the middle class relative to the rich since the former hold a much higher share of their assets in homes than the latter. ${ }^{17}$

There is a pronounced difference in the valuation of liquid assets when interest based on the Federal funds rate is accrued over time. What is the logic of including accrued interest on liquid assets? As noted above, one could argue that interest accrual is a direct result of Fed actions in the form of setting the Federal funds rate. Since the objective of this analysis is to analyze the direct effects of Fed actions on wealth inequality, it may make sense to also include the Fed's effect on the accumulation of liquid assets over time. Without adding accrued interest, the real value of liquid assets declined by 144.8 percent between 1983 and 2019 as it was eaten up by inflation. When liquid assets are accrued at the Federal funds rate minus the inflation rate, its value showed a 60.8 percent gain. The real Federal funds rate was positive from 1983 through 2002, showed a mixed pattern from 2003 through 2009, turned negative from 2010 to 2018, and became positive in 2019. The percentage gain in the real value of liquid assets accrued using the Federal funds rate was greater than the no interest case in each of the sub-periods but the disparity was much greater in 1983-1989 and 1989-2001 than in the later years. Adding interest

\footnotetext{
${ }^{17}$ The only other long terms series on mortgage rates that I could find is for a 15-year mortgage. However, this series begins only in 1991.
} 
accruals to liquid assets in comparison to the no interest case will benefit the middle class relative to the rich since the former hold a higher share of their assets in liquid form than the latter.

Table 15 analyzes whether the base case results on wealth inequality shown in Table 8 hold up using alternative returns to assets. The actual change in the ratio of the mean wealth of the top one percent to median wealth was 142.4 over the 1983-2019 period. In the base case, the change in the ratio resulting from the change in asset prices amounted to -136.1. That is to say, asset price changes were highly equalizing. When the 20-year real Treasury rate is used instead of the10-year rate, as shown in Scenario I, the net effect of asset price changes is still equalizing but less so - only -116.1 - and when the 30-year bond rate is used as in Scenario III, the effect is once again mitigated but not reversed to -101.6. The use of 20-year and 30-year bonds reduces the effect of asset price changes relative to 10-year bonds in all sub-periods except 2007-2010 and 2016-2019.

These results may seem surprising since the use of a longer term bond rate benefits the rich relative to the middle class as noted above. Further analysis reveals why. The use of the 30year bond relative to the 10-year bond raises the contribution of stock price changes to raising the mean wealth of the top percentile from 6.8 to 22.5 percent, that of bond prices from 7.5 to 15.9 percent, and that of businesses from 11.4 to 38.0 percent over years 1983-2019. Altogether, the contribution of asset price changes rises from 53.4 to 104.2 percent. However, there are also gains for the middle class. The contribution of stock, bond, and business prices to median wealth increases from 12.2 to 31.9 percent and the total contribution of asset price changes from 204.9 to 224.6 percent. As a result, asset price changes based on the 30-year bond rate still increase median wealth relative to the top percentile wealth.

Scenario III is based on 10-year instead of 30-year mortgage rates. The use of shorter mortgages disfavors the middle class relative to the rich so that the effect of asset prices is once again attenuated but not reversed (from -136.1 to -101.6). Accruing interest on liquid assets favors the middle class relative to the rich, so that including accrued interest, as in Scenario IV, now augments the effect of asset price changes from -136.1 to -141.0. Finally, combining the use of 30-year bonds and 10-year mortgages, as in Scenario V, reduces the effect of asset price changes from the base case level of -136.1 to -55.1 but does not overturn the base case result. 
The only exception is the 1983-1989 period when the combined effect is actually slightly disequalizing.

Results are quite similar using the change in the Gini coefficient. Over the full period, 1983-2019, the Gini coefficient decreases from asset price changes for Scenarios I through IV and shows essentially no change in Scenario V. Falloffs are recorded for all sub-periods as well with the exception of 1983-1989 for Scenario V, which shows no change. The rank order in results is also very similar. For the 1983-2019 period, the reduction is greatest for Scenario IV, which assumes that interest on liquid assets accrues over time at the Federal funds rate. This assumption strongly augments the wealth of the middle class. The base case ranks second, Scenario I ranks third, Scenarios II and III are virtually tied for fourth place, and Scenario V ranks last.

\section{Concluding Remarks}

Is the Fed implicated in the sharp run-up of household wealth inequality in the U.S. since the early 1980s? According to my analysis, the Fed is completely exonerated. Indeed, if anything, Fed actions have lowered wealth inequality rather than raising it. The effect is quite sizeable, with the Gini coefficient declining by 0.045 over the full $1983-2019$ period as a result of asset price changes engendered by the Fed. The reason is that Fed policy has boosted home prices a lot more in percentage terms than stock, business, and bond values. It has also had a pronounced effect on reducing the real value of debt despite the moderate level of inflation. Both of these results benefit the middle class a lot more than the rich. Fed policy also benefited Black and Hispanic households more than white households and for the same reasons: the former hold a much larger share of their assets in their own homes and a smaller share in financial assets than the latter and also have a much higher degree of relative indebtedness. Asset price changes and debt devaluation resulting from monetary policy, moreover, accounted for 72.6 percent of the advance of mean wealth over years 1983-2019. They also would have led to a 204.9 percent gain in median wealth over these years, compared to the actual advance of 23.4 percent.

These results remain robust with respect to alternative choices of bond and mortgage interest rates as well as the treatment of liquid assets. Alternative scenarios might mitigate but do not reverse base case results. 
Why the difference in results between this study and earlier ones? Greenwald et. al. (2021), for example, find a substantial disequalizing effect of falling interest rates on financial wealth inequality in the U.S. for a comparable period. Compared to previous studies based on indirect techniques, this one find a smaller effect on equity prices (and business values) and much larger effects on house prices. The house price impact overwhelmingly dominates the bond and stock price effects. Also, this paper finds a large effect from inflation due to leverage, particularly compared to most studies which exclude this factor. This influence operates consistently throughout the 1983-2019 period. One exception is Bunn et. al. (2018) who do include the impact of inflation and find that monetary policy is equalizing, though the effect they estimate is quite small.

What are the relative merits of the indirect approaches employed in previous studies and the direct approach used here? The indirect approach is based on how markets react to a change in monetary policy such as a reduction in the Federal funds rate. But is the Fed responsible for how the markets react to its actions? Should the Fed be "charged" for these reactions? A lowering of the Federal Funds rate often leads to a rise in stock prices as investors foresee an uptick in future profits. However, this is not a direct consequence of Fed policy, which is reflected only in the change in the discount rate used to compute the present value of future profits (see equation 1). My view is that market reactions are not the responsibility of the Fed and should be ignored in assessing the effects of monetary policy on household wealth.

Are the results of this study inconsistent with Bartscher et. al. (2021)? As discussed above, they find that accommodative monetary policy led to capital gains equivalent to 20-30 percent of white mean income but only about 10 percent of Black mean income. How does this relate to the racial wealth gap? Using the 2019 ratio of mean income to mean wealth by race based on SCF data, I can approximate how their results relate to the closure of the racial wealth gap. The ratio for white households was 7.86 and that for Black households was 2.29. Using a 30 percent gain for white income and a 10 percent gain for Black income, this would roughly imply that soft money policy caused a 3.8 percent gain in mean white net worth but a 4.4 percent gain in mean Black net worth. So even in the Bartscher et. al. analysis, soft money policy would have lowered the racial wealth ratio.

The results also indicate that a policy of low interest rates and moderate inflation benefited younger households relative to older ones. The reason is that the former hold a higher 
percentage of their assets in their own homes and have a much higher degree of relative indebtedness.

The results reported in this paper are more general than the U.S. It applies to any nation which has seen a secular decline in interest and inflation rates. Indeed, as Rachel and Summers (2019) among others has documented, the secular decline in interest rates characterizes a wide swath of advanced industrial economies, including, besides the U.S., Canada, France, Germany, Japan, and the U.K.

What are the limitations of this study? The simulation exercise in this paper focuses on the impact of changes in interest rates and inflations rates on asset prices and correspondingly on wealth inequality, abstracting from active portfolio shifts by households. In particular, it is assumed that households do not adjust their portfolio composition in response to changes in relative asset prices (that is, there is no substitution effect and no behavioral response). This is also the case with the other studies cited above.

On a policy note, how does this work inform Federal Reserve policy on inequality and racial equity issues, particularly on the effects of tamping down inflation? One could say that the Fed has already been successful in reducing wealth inequality and the racial/ethnic wealth gap and in promoting household wealth growth. However, boosting inflation somewhat ironically would lower wealth inequality and the racial/ethnic wealth gap even more and promote even greater growth in household wealth. Indeed, the Fed's 2 percent target rate for price inflation would not achieve these objectives. Certainly, a higher rate of inflation would benefit the middle class more relative to the rich and minorities relative to whites.

\section{$\underline{\text { References }}$}

Adam, Klaus, and Panagiota Tzamourani (2016), “Distributional Consequences of Asset Price Inflation in the Euro Area, European Economic Review, 89(C), 172-192.

Amberg, Niklas, Thomas Jansson, Mathias Klein, Anna Rogantini Picco (2021), “Five Facts about the Distributional Income Effects of Monetary Policy,” CESifo Working Paper 9062, May.

Ampudia, Miguel, Dimitris Georgarakos, Jiri Slacek, Oreste Tristani, Phillip Vermeulen, and Giovanni L. Volante (2018), “Monetary policy and household inequality,” European Central Bank Working Paper No. 2170, July. 
Andersen, Asger Lau, Niels Johannesen, Jørgensen, Mia, and José-Luis Peydro (2021), “Monetary Policy and Inequality,” Mimeo, May 21.

Bartscher, Alina, Moritz Kuhn, Moritz Schularick, and Paul Wachtel (2021), "Monetary Policy and Racial Inequality,” Federal Reserve Bank of New York Staff Report No. 959, January.

Bricker, J., Hansen, P., \& Volz, A. H. (2019), "Wealth concentration in the US after augmenting the upper tail of the survey of consumer finances,” Economics Letters, 184, 108659.

Bricker, Jesse, Alice Henriques, Jacob Krimmel, and John Sabelhaus (2015), “The Increase in Wealth Concentration, 1989-2013,” Federal Reserve FEDS Notes.

Bricker, Jesse, Alice Henriques, Jacob Krimmel, and John Sabelhaus (2016a), "Estimating Top Income and Wealth Shares: Sensitivity to Data and Methods," American Economic Review Papers \& Proceedings, 106 (5), 641-645.

Bricker, Jesse, Jacob Krimmel, Alice Henriques, and John Sabelhaus (2016b), “Measuring Income and Wealth at the Top Using Administrative and Survey Data,” Brookings Papers on Economic Activity, Spring, 261-312.

Bunn, Philip, Alice Pugh, and Chris Yeates (2018), “The Distributional Impact of Monetary Policy Easing in the UK Between 2008 and 2014,” Staff working paper 720, Bank of England.

Campbell, John Y., and Robert J. Shiller (1998), "Valuation Ratios and the Long-Run Stock Market Outlook,” Journal of Portfolio Management, 24(2), Winter, 11-26.

Casiraghi, Marco, Eugenio Gaiotti, Lisa Rodano, and Alessandro Secchi (2018), “A Reverse Robin Hood? The Distributional Implications of Non-standard Monetary Policy for Italian Households,” Journal of International Money and Finance 85, 215-235.

Coibion, Olivier, Yuriy Gorodnichenko, Lorenz Kueng, and John Silvia (2017), “Innocent Bystanders? Monetary Policy and Inequality,” Journal of Monetary Economics, 88(C), 70-89.

Davtyan, Karen (2016), “Income Inequality and Monetary Policy: An Analysis on the Long Run Relation,” Research Institute of Applied Economics Working Paper No. 2016/04.

Domanski, Dietrich, Michela Scatigna, and Anna Zabai (2016), "Wealth Inequality and Monetary Policy,” BS Quarterly Review, March, 45-64. 
Duca, John V., and John Muellbauer with Anthony Murphy (2021), "What Drives House Price Cycles? International Experience and Policy Issues,” Journal of Economic Literature, 59(3), 773-864.

Frost, J., and A. Saiki (2014), "How does unconventional monetary policy affect inequality? Evidence from Japan,” DNB Working Papers no. 423.

Gabriel Stuart, and Chandler Lutz (2017), “The impact of unconventional monetary policy on real estate markets,” mimeo, available at SSRN: https://ssrn.com/abstract=2493873.

Gomez, Matthieu , and Emilien Gouin-Bonenfant (2020), “A Q-Theory of Inequality,” Mimeo, Columbia University, October.

Greenwald, Daniel L., Matteo Leombroni, Hanno Lustig, and Stijn Van Nieuwerburgh (2021), “Financial and Total Wealth Inequality with Declining Interest Rates,” NBER Working Paper No. 28613, April.

Guerello, Chiara (2018), “Conventional and Unconventional Monetary Policy vs. Households Income Distribution: An Empirical Analysis for the Euro Area,” Journal of International Money and Finance, 85(C), 187-214.

Hafemann, Lucas, Paul Rudel, and Joerg Schmidt (2018), “Moving Closer or Drifting Apart: Distributional Effects of Monetary Policy,” Supplement to The Manchester School 86(S1), September, 10-136.

Kennickell, Arthur B., and R. Louise Woodburn (1999), "Consistent Weight Design for the 1989, 1992, and 1995 SCFs, and the Distribution of Wealth," Review of Income and Wealth 45(2), 193-216.

Kopczuk, W. (2015). “What Do We Know about the Evolution of Top Wealth Shares in the United States?” Journal of Economic Perspectives, 29(1), 47-66.

Lenza, Michele, and Jiri Slacalek (2018), “How does monetary policy affect income and wealth inequality? Evidence from quantitative easing in the euro area,” European Central Bank Working Paper No. 2190, October.

Mumtaz, Haroon, and Angeliki Theophilopoulou (2017), “The Impact of Monetary Policy on Inequality in the UK. An Empirical Analysis,” European Economic Review, 98(C), 410-423. 
Peersman, Gert, and Frank Smets (2001), “The Monetary Transmission Mechanism in the Euro Area: More Evidence from VAR Analysis,” working paper series 91, European Central Bank.

Pfeffer, Fabian T., Sheldon H. Danziger, and Robert F. Schoeni (2013), "Wealth Disparities Before and After the Great Recession.” Annals of the American Academy of Political and Social Science, 650(1), 98-123.

Rachel, Łukasz, and Lawrence H. Summers (2019), "On Secular Stagnation in the Industrialized World,” NBER Working Paper No. 26198, August.

Saez, Emmanuel and Gabriel Zucman (2016), "Wealth Inequality in the United States since 1913: Evidence from Capitalized Income Tax Data,” Quarterly Journal of Economics, 131(2), 519-578.

Shiller, Robert J., Laurence Black, and Farouk, Jivra (2020), “Making Sense of Sky High Stock Prices,” Project Syndicate, May 30.

Smith, Matthew, Owen Zidar, and Eric Zwick, (2019), “Top Wealth in the United States: New Estimates and Implications for Taxing the Rich,” Mimeo.

Wolff, Edward N. (1979), "The Distributional Effects of the 1969-1975 Inflation on Household Wealth Holdings in the United States," The Review of Income and Wealth, 25(2), 195-207.

Wolff, Edward N. (2017), A Century of Wealth in America, Cambridge, MA: Harvard University Press.

Wolff, Edward N. (2021), "Household Wealth Trends in the United States, 1962 to 2019: Median Wealth Rebounds... But Not Enough,” NBER Working Paper No. 28383, January. 


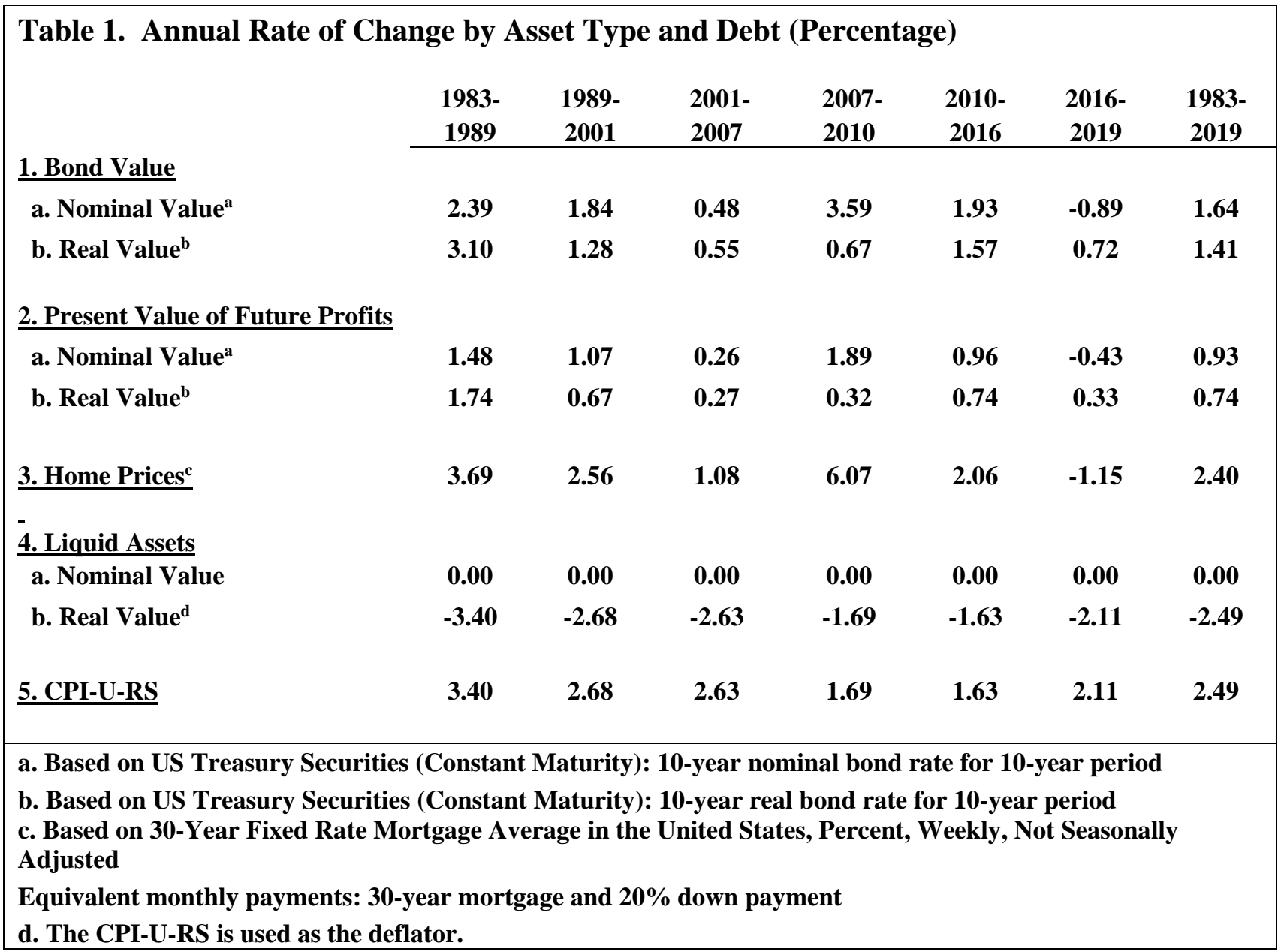




\begin{tabular}{|c|c|c|c|c|c|c|c|c|}
\hline \multicolumn{9}{|c|}{$\begin{array}{l}\text { Table 2. Mean and Median Net Worth, Selected Years, 1983-2019 } \\
\text { (In thousands, } 2019 \text { dollars) }\end{array}$} \\
\hline Variable & & 1983 & 1989 & 2001 & 2007 & 2010 & 2016 & 2019 \\
\hline \multirow{2}{*}{$\begin{array}{l}\text { 1. Median } \\
\text { 2. Mean }\end{array}$} & & 81.7 & 88.8 & 106.4 & 126.7 & 71.0 & 83.2 & 100.8 \\
\hline & & 318.0 & 369.9 & 550.3 & 662.6 & 556.2 & 711.3 & 723.8 \\
\hline \multirow{4}{*}{$\begin{array}{l}\text { 1. Median } \\
\text { 2. Mean }\end{array}$} & \multicolumn{4}{|c|}{ Annual Growth Rate (percent) } & & \multicolumn{2}{|c|}{ Percentage Change } & \\
\hline & $\begin{array}{c}1983- \\
1989\end{array}$ & $\begin{array}{l}1989- \\
2007\end{array}$ & $\begin{array}{l}2007- \\
2010\end{array}$ & $\begin{array}{l}2010- \\
2016\end{array}$ & $\begin{array}{l}2016- \\
2019\end{array}$ & $\begin{array}{c}2007- \\
2010\end{array}$ & $\begin{array}{l}2010- \\
2016\end{array}$ & $\begin{array}{l}2016- \\
2019 \\
\end{array}$ \\
\hline & 1.39 & 1.98 & -19.28 & 2.63 & 6.40 & -43.9 & 17.1 & 21.2 \\
\hline & 2.52 & 3.24 & -5.84 & 4.10 & 0.58 & -16.1 & 27.9 & 1.8 \\
\hline
\end{tabular}

\begin{tabular}{|c|c|c|c|c|c|c|c|c|c|c|c|}
\hline \multirow[b]{2}{*}{ Year } & \multirow[b]{2}{*}{$\begin{array}{l}\text { Gini } \\
\text { Coeff. }\end{array}$} & \multicolumn{8}{|c|}{ Percentage Share of Wealth Held by: } & \multirow[b]{2}{*}{\begin{tabular}{|l|} 
Bottom \\
$20.0 \%$ \\
\end{tabular}} & \multirow[b]{2}{*}{ All } \\
\hline & & $\begin{array}{l}\text { Top } \\
1.0 \% \\
\end{array}$ & $\begin{array}{l}\text { Next } \\
4.0 \% \\
\end{array}$ & $\begin{array}{l}\text { Next } \\
5.0 \% \\
\end{array}$ & $\begin{array}{l}\text { Next } \\
10.0 \% \\
\end{array}$ & \begin{tabular}{|l|l} 
Top \\
$20.0 \%$ \\
\end{tabular} & $\begin{array}{l}\text { 4th } \\
20.0 \% \\
\end{array}$ & \begin{tabular}{l|l} 
3rd \\
$20.0 \%$ \\
\end{tabular} & $\begin{array}{l}\text { 2nd } \\
20.0 \% \\
\end{array}$ & & \\
\hline \multicolumn{12}{|c|}{ A. Net Worth } \\
\hline 1983 & $\overline{0.799}$ & 33.8 & 22.3 & 12.1 & 13.1 & 81.3 & 12.6 & 5.2 & 1.2 & -0.3 & 100.0 \\
\hline 1989 & 0.828 & 35.2 & 22.8 & 11.9 & 13.2 & 83.0 & 12.0 & 4.7 & 0.9 & -0.7 & 100.0 \\
\hline 2001 & 0.826 & 33.4 & 25.8 & 12.3 & 12.9 & 84.4 & 11.3 & 3.9 & 0.7 & -0.4 & 100.0 \\
\hline 2007 & 0.834 & 34.6 & 27.3 & 11.2 & 12.0 & 85.0 & 10.9 & 4.0 & 0.7 & -0.5 & 100.0 \\
\hline 2010 & 0.866 & 35.1 & 27.4 & 13.8 & 12.3 & 88.6 & 9.5 & 2.7 & 0.3 & -1.2 & 100.0 \\
\hline 2016 & 0.877 & 39.6 & 27.1 & 12.1 & 11.1 & 89.9 & 8.2 & 2.4 & 0.3 & -0.8 & 100.0 \\
\hline 2019 & 0.869 & 38.2 & 28.2 & 11.6 & 10.8 & 88.9 & 8.6 & 2.9 & 0.4 & -0.8 & 100.0 \\
\hline
\end{tabular}




\begin{tabular}{|c|c|c|c|c|c|c|c|}
\hline Wealth component & 1983 & 1989 & 2001 & 2007 & 2010 & 2016 & 2019 \\
\hline Principal residence & 30.1 & 30.2 & 28.2 & 32.8 & 30.7 & 25.1 & 26.9 \\
\hline Other real estate $^{a}$ & 14.9 & 14.0 & 9.8 & 11.3 & 11.6 & 10.4 & 9.4 \\
\hline Unincorporated business equity ${ }^{b}$ & 18.8 & 17.2 & 17.2 & 20.1 & 17.7 & 20.1 & 20.0 \\
\hline $\begin{array}{l}\text { Liquid assets }^{\mathrm{c}} \\
\text { Securities, directly or indirectly }\end{array}$ & 17.4 & 17.5 & 8.8 & 6.6 & 7.7 & 6.7 & 6.8 \\
\hline owned $^{\mathrm{d}, \mathrm{e}}$ & 6.0 & 6.0 & 9.7 & 10.8 & 13.0 & 13.9 & 12.9 \\
\hline Stocks, directly or indirectly owned & 11.3 & 10.2 & 24.5 & 16.8 & 17.5 & 22.4 & 22.6 \\
\hline Miscellaneous assets ${ }^{\mathrm{f}}$ & 1.3 & 4.9 & 1.8 & 1.7 & 1.7 & 1.3 & 1.4 \\
\hline Total Assets & 100.0 & 100.1 & 100.0 & 100.0 & 100.0 & 100.0 & 100.0 \\
\hline Debt on principal residence & 6.3 & 8.6 & 9.4 & 11.4 & 12.7 & 8.6 & 9.1 \\
\hline All other debt ${ }^{g}$ & 6.8 & 6.4 & 3.1 & 3.9 & 4.4 & 3.9 & 3.8 \\
\hline Total debt & 13.1 & 15.0 & 12.5 & 15.3 & 17.1 & 12.5 & 12.9 \\
\hline
\end{tabular}

Source: author's computations from the 1983-2019 SCF.

a. In 2001, 2004, and 2007, this equals the gross value of other residential real estate plus the net equity in non-residential real estate.

b. Net equity in unincorporated farm and non-farm businesses and closely-held corporations.

c. Checking accounts, savings accounts, time deposits, money market funds, certificates of deposits, and the cash surrender value of life insurance.

d. Corporate bonds, government bonds (including savings bonds), open-market paper, and notes.

e. Includes direct ownership and indirect ownership through mutual funds, trusts, and

IRAs,

Keogh plans, 401(k) plans, and other retirement accounts

f. Gold and other precious metals, royalties, jewelry, antiques, furs, loans to friends and relatives, future contracts, and miscellaneous

assets.

g. Mortgage debt on all real property except principal residence; credit card, installment, and other debt. 


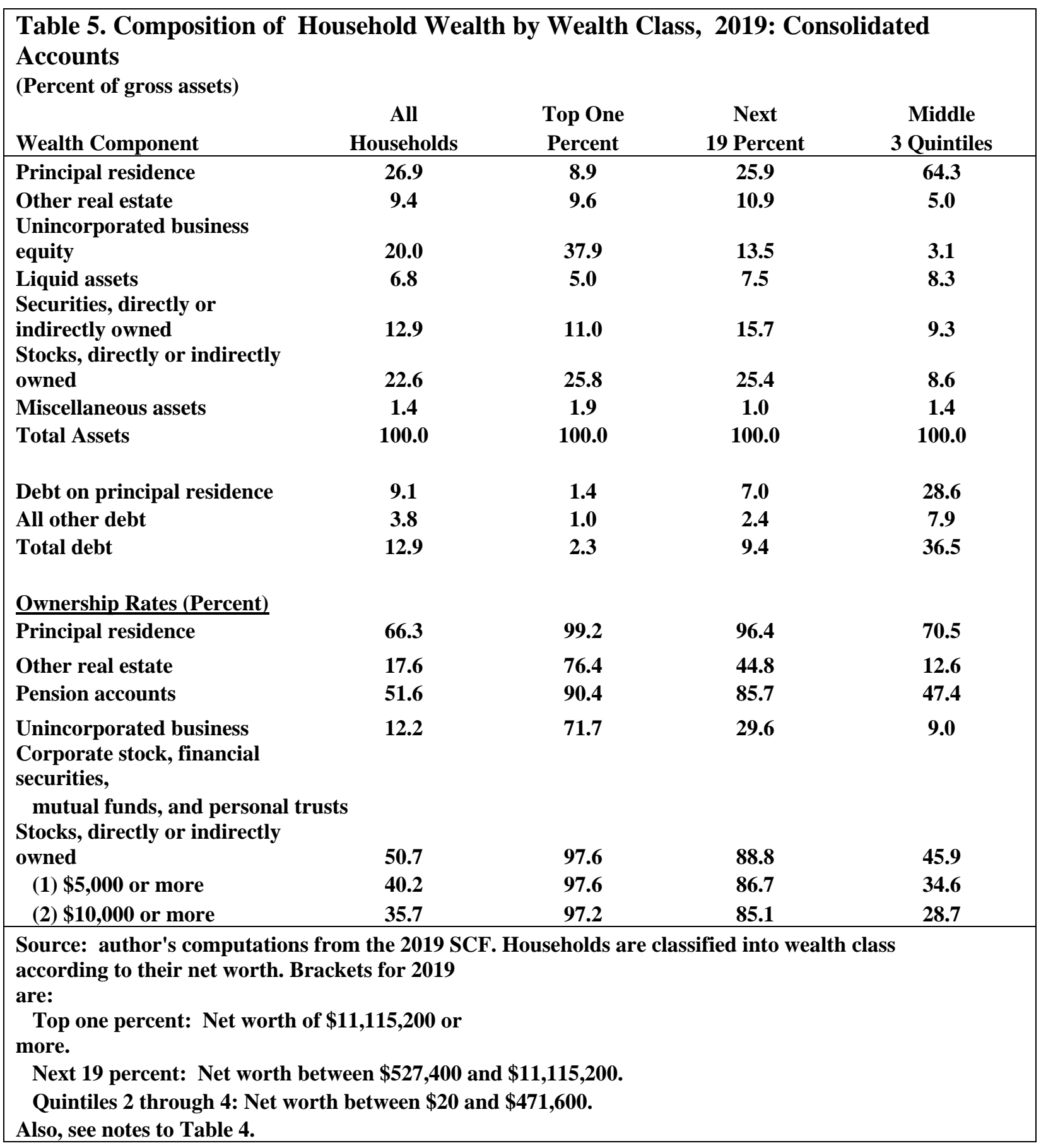




\begin{tabular}{|c|c|c|c|c|c|c|c|}
\hline \multicolumn{8}{|c|}{$\begin{array}{l}\text { Table 6. Composition of Household Wealth of the Middle Three Wealth Quintiles, 1983- } \\
\text { 2019: Consolidated Accounts } \\
\text { (Percent of gross assets) }\end{array}$} \\
\hline Wealth component & 1983 & 1989 & 2001 & 2007 & 2010 & 2016 & 2019 \\
\hline Principal residence & 61.6 & 61.7 & 59.2 & 65.1 & 64.8 & 61.9 & 64.3 \\
\hline Other real estate & 7.8 & 5.7 & 5.2 & 6.4 & 5.6 & 5.1 & 5.0 \\
\hline Unincorporated business equity & 3.6 & 3.8 & 3.4 & 2.9 & 3.2 & 2.8 & 3.1 \\
\hline $\begin{array}{l}\text { Liquid assets } \\
\text { Securities, directly or indirectly }\end{array}$ & 21.4 & 18.6 & 12.1 & 7.8 & 8.0 & 8.5 & 8.3 \\
\hline owned & 1.9 & 4.0 & 6.3 & 9.5 & 8.9 & 10.8 & 9.3 \\
\hline Stocks, directly or indirectly owned & 2.4 & 3.3 & 12.6 & 7.0 & 8.1 & 9.7 & 8.6 \\
\hline Miscellaneous assets & 1.3 & 2.9 & 1.2 & 1.3 & 1.3 & 1.2 & 1.4 \\
\hline Total assets & 100.0 & 100.0 & 100.0 & 100.0 & 100.0 & 100.0 & 100.0 \\
\hline Debt on principal residence & 17.7 & 22.5 & 25.4 & 30.3 & 33.4 & 28.5 & 28.6 \\
\hline All other debt & 9.5 & 6.9 & 6.3 & 7.6 & 7.5 & 8.5 & 7.9 \\
\hline Total debt & 27.2 & 29.5 & 31.7 & 37.9 & 40.9 & 37.1 & 36.5 \\
\hline \multicolumn{8}{|l|}{ Ownership Rates (Percent) } \\
\hline Principal residence & 71.6 & 71.5 & 75.9 & 78.2 & 76.9 & 68.0 & 70.5 \\
\hline Other real estate & 15.4 & 15.5 & 13.2 & 13.6 & 14.7 & 12.4 & 12.6 \\
\hline Pension assets & 12.2 & 27.3 & 52.9 & 51.4 & 53.4 & 45.8 & 47.4 \\
\hline Unincorporated business & 8.5 & 8.4 & 7.9 & 8.1 & 8.8 & 8.2 & 9.0 \\
\hline $\begin{array}{l}\text { Corporate stock, financial securities, } \\
\text { mutual funds, and personal trusts }\end{array}$ & 21.6 & 24.2 & 27.5 & 27.1 & 23.1 & 15.3 & 16.8 \\
\hline Stocks, directly or indirectly owned & 16.5 & 29.4 & 51.1 & 49.7 & 47.8 & 41.4 & 45.9 \\
\hline
\end{tabular}




\begin{tabular}{|c|c|c|c|c|c|c|c|}
\hline \multicolumn{8}{|c|}{$\begin{array}{l}\text { Table 7. Composition of Household Wealth of the Top One Percent, 1983-2019: } \\
\text { Consolidated Accounts } \\
\text { (Percent of gross assets) }\end{array}$} \\
\hline Wealth component & 1983 & 1989 & 2001 & 2007 & 2010 & 2016 & 2019 \\
\hline Principal residence & 8.1 & 7.6 & 8.4 & 10.2 & 9.4 & 7.6 & 8.9 \\
\hline Other real estate & 19.9 & 22.4 & 11.4 & 10.6 & 13.7 & 11.7 & 9.6 \\
\hline Unincorporated business equity & 32.1 & 37.6 & 32.9 & 41.7 & 36.1 & 37.2 & 37.9 \\
\hline Liquid assets & 8.5 & 8.2 & 5.7 & 4.5 & 6.2 & 4.6 & 5.0 \\
\hline Securities, directly or indirectly owned & 9.2 & 11.2 & 11.7 & 9.6 & 12.4 & 11.9 & 11.0 \\
\hline Stocks, directly or indirectly owned & 21.2 & 9.4 & 27.4 & 21.4 & 20.7 & 25.5 & 25.8 \\
\hline Miscellaneous assets & 1.0 & 3.7 & 2.6 & 2.0 & 1.6 & 1.4 & 1.9 \\
\hline Total assets & 100.0 & 100.0 & 100.0 & 100.0 & 100.0 & 100.0 & 100.0 \\
\hline Debt on principal residence & 0.7 & 0.9 & 1.5 & 1.5 & 1.8 & 1.2 & 1.4 \\
\hline All other debt & 4.8 & 1.5 & 0.9 & 1.2 & 1.6 & 1.2 & 1.0 \\
\hline Total debt & 5.5 & 2.4 & 2.4 & 2.7 & 3.4 & 2.4 & 2.3 \\
\hline \multicolumn{8}{|l|}{ Ownership Rates (Percent) } \\
\hline Principal residence & 92.3 & 85.9 & 97.5 & 98.8 & 98.1 & 94.1 & 99.2 \\
\hline Other real estate & 79.1 & 80.3 & 76.3 & 76.0 & 74.6 & 74.7 & 76.4 \\
\hline Pension assets & 56.7 & 71.5 & 89.3 & 87.7 & 90.3 & 91.3 & 90.4 \\
\hline Unincorporated business & 74.2 & 72.5 & 71.9 & 73.8 & 74.5 & 66.1 & 71.7 \\
\hline $\begin{array}{l}\text { Corporate stock, financial securities, } \\
\text { mutual funds, and personal trusts }\end{array}$ & 84.3 & 93.5 & 90.4 & 85.3 & 88.9 & 89.2 & 91.1 \\
\hline Stocks, directly or indirectly owned & 76.8 & 85.8 & 95.0 & 92.6 & 94.9 & 94.0 & 97.6 \\
\hline
\end{tabular}




\begin{tabular}{|c|c|c|c|c|c|c|c|}
\hline & $\begin{array}{c}1983- \\
1989 \\
\end{array}$ & $\begin{array}{l}1989- \\
2001\end{array}$ & $\begin{array}{l}2001- \\
2007\end{array}$ & $\begin{array}{l}2007- \\
2010\end{array}$ & $\begin{array}{r}2010- \\
2016\end{array}$ & $\begin{array}{r}2016- \\
2019\end{array}$ & $\begin{array}{r}1983- \\
2019\end{array}$ \\
\hline \multicolumn{8}{|l|}{ A. Mean Net Worth } \\
\hline 1. Actual Percentage Change & 16.3 & 48.8 & 20.4 & -16.1 & 27.9 & 1.8 & 127.6 \\
\hline \multicolumn{8}{|l|}{ changes } \\
\hline 2a. Stocks & 1.4 & 1.7 & 0.4 & 0.2 & 1.1 & -0.3 & 6.3 \\
\hline 2b. Homes & 8.7 & 12.2 & 2.4 & 7.6 & 4.3 & 1.0 & 46.6 \\
\hline 2c. Businesses & 2.3 & 1.7 & 0.4 & 0.2 & 1.0 & -0.2 & 6.6 \\
\hline 2d. Liquid assets & -4.6 & -5.8 & -1.5 & -0.4 & -0.9 & -0.5 & -17.2 \\
\hline 2e. Non-home real estate & 4.2 & 5.0 & 0.8 & 2.7 & 1.7 & 0.4 & 18.6 \\
\hline 2f. Bonds & 1.4 & 1.5 & 0.4 & 0.3 & 1.6 & -0.3 & 8.0 \\
\hline 2g. Debt & 3.7 & 6.1 & 2.8 & 1.0 & 1.8 & 1.0 & 23.7 \\
\hline \multicolumn{8}{|l|}{ 3. Percentage decomposition } \\
\hline $\begin{array}{l}\text { a. Total effect from asset price } \\
\text { changes }\end{array}$ & 104.9 & 45.7 & 27.4 & -71.9 & 37.9 & 57.9 & 72.6 \\
\hline 2a. Stocks & 8.5 & 3.4 & 1.9 & -1.2 & 3.8 & -14.5 & 4.9 \\
\hline 2b. Homes & 53.3 & 24.9 & 11.7 & -47.1 & 15.5 & 57.2 & 36.5 \\
\hline 2c. Businesses & 14.1 & 3.4 & 1.7 & -1.4 & 3.6 & -12.9 & 5.2 \\
\hline 2d. Liquid assets & -28.2 & -11.8 & -7.5 & 2.8 & -3.1 & -28.7 & -13.5 \\
\hline 2e. Non-home real estate & 25.6 & 10.2 & 4.0 & -16.9 & 6.1 & 21.8 & 14.6 \\
\hline 2f. Bonds & 8.8 & 3.1 & 2.0 & -1.8 & 5.6 & -18.9 & 6.3 \\
\hline 2g. Debt & 22.7 & 12.4 & 13.6 & -6.3 & 6.4 & 54.0 & 18.6 \\
\hline \multicolumn{8}{|l|}{ B. Median Net Worth } \\
\hline 1. \%Change & 8.7 & 19.9 & 19.0 & -43.9 & 17.1 & 21.2 & 23.4 \\
\hline $\begin{array}{l}\text { 2. \%Change from asset price } \\
\text { changes }\end{array}$ & 28.1 & 45.0 & 14.3 & 26.6 & 22.5 & 6.1 & 204.9 \\
\hline 2a. Stocks & 0.4 & 1.0 & 0.2 & 0.1 & 0.7 & -0.1 & 3.4 \\
\hline 2b. Homes & 21.3 & 31.3 & 6.4 & 21.4 & 13.7 & 3.4 & 131.2 \\
\hline 2c. Businesses & 0.6 & 0.4 & 0.1 & 0.0 & 0.2 & 0.0 & 1.5 \\
\hline 2d. Liquid assets & -6.3 & -8.4 & -2.6 & -0.7 & -1.4 & -0.9 & -26.7 \\
\hline 2e. Non-home real estate & 2.3 & 2.8 & 0.6 & 2.0 & 1.2 & 0.3 & 12.2 \\
\hline 2f. Bonds & 0.8 & 1.2 & 0.4 & 0.3 & 1.6 & -0.3 & 7.3 \\
\hline 2g. Debt & 8.9 & 16.7 & 9.1 & 3.4 & 6.6 & 3.8 & 75.9 \\
\hline \multicolumn{8}{|l|}{ 3. Percentage decomposition } \\
\hline $\begin{array}{l}\text { a. Total effect from asset price } \\
\text { changes }\end{array}$ & 324.4 & 226.3 & 74.9 & -60.5 & 131.6 & 28.6 & 875.1 \\
\hline 2a. Stocks & 5.1 & 4.8 & 1.3 & -0.3 & 3.9 & -0.7 & 14.6 \\
\hline 2b. Homes & 245.9 & 157.2 & 33.7 & -48.7 & $\mathbf{8 0 . 0}$ & 16.0 & 560.5 \\
\hline 2c. Businesses & 6.5 & 2.2 & 0.4 & -0.1 & 1.3 & -0.2 & 6.4 \\
\hline 2d. Liquid assets & -72.9 & -42.2 & -13.7 & 1.5 & -8.1 & -4.1 & -114.1 \\
\hline 2e. Non-home real estate & 26.9 & 14.1 & 3.1 & -4.5 & 6.8 & 1.3 & 52.1 \\
\hline 2f. Bonds & 9.7 & 6.2 & 2.2 & -0.7 & 9.3 & -1.6 & 31.3 \\
\hline 2g. Debt & 103.2 & 83.9 & 48.0 & -7.7 & 38.5 & 18.0 & 324.2 \\
\hline
\end{tabular}




\begin{tabular}{|c|c|c|c|c|c|c|c|}
\hline 1. Actual Percentage Change & 21.2 & 41.4 & 24.6 & -15.5 & 45.4 & -1.9 & 157.2 \\
\hline 2. \%Change from asset price & 14.4 & 14.0 & 2.4 & 5.2 & 6.6 & -0.4 & 53.4 \\
\hline \multicolumn{8}{|l|}{ changes } \\
\hline 2a. Stocks & 1.8 & 1.6 & 0.4 & 0.2 & 1.1 & -0.3 & 6.8 \\
\hline 2b. Homes & 2.0 & 3.0 & 0.6 & 2.0 & 1.2 & 0.3 & 12.2 \\
\hline 2c. Businesses & 4.0 & 3.0 & 0.6 & 0.4 & 1.7 & -0.4 & 11.4 \\
\hline 2d. Liquid assets & -2.0 & -2.7 & -0.9 & -0.3 & -0.6 & -0.3 & -9.1 \\
\hline 2e. Non-home real estate & 5.5 & 6.2 & 0.8 & 2.5 & 1.7 & 0.4 & 20.1 \\
\hline 2f. Bonds & 2.2 & 1.9 & 0.4 & 0.2 & 1.2 & -0.3 & 7.5 \\
\hline 2g. Debt & 0.9 & 0.9 & 0.4 & 0.2 & 0.3 & 0.2 & 4.5 \\
\hline \multicolumn{8}{|l|}{ 3. Percentage decomposition } \\
\hline $\begin{array}{l}\text { a. Total effect from asset price } \\
\text { changes }\end{array}$ & 67.9 & 33.7 & 9.6 & -33.6 & 14.6 & 21.7 & 34.0 \\
\hline 2a. Stocks & 8.3 & 3.8 & 1.7 & -1.3 & 2.4 & 14.0 & 4.3 \\
\hline 2b. Homes & 9.6 & 7.1 & 2.6 & -13.0 & 2.5 & -15.3 & 7.8 \\
\hline 2c. Businesses & 18.9 & 7.3 & 2.5 & -2.5 & 3.8 & 20.5 & 7.3 \\
\hline 2d. Liquid assets & -9.3 & -6.5 & -3.6 & 1.8 & -1.3 & 17.2 & -5.8 \\
\hline 2e. Non-home real estate & 25.8 & 15.1 & 3.1 & -16.1 & 3.8 & -19.8 & 12.8 \\
\hline 2f. Bonds & 10.2 & 4.7 & 1.5 & -1.5 & 2.7 & 13.6 & 4.8 \\
\hline 2g. Debt & 4.4 & 2.2 & 1.8 & -1.1 & 0.7 & -8.4 & 2.9 \\
\hline \multicolumn{8}{|c|}{ D. Ratio of the Mean Wealth of the Top One Percent to Median Wealth } \\
\hline 1. Change in the actual ratio & 15.1 & 26.3 & 8.0 & 91.5 & 65.8 & -64.3 & 142.4 \\
\hline $\begin{array}{l}\text { 2. Change in the ratio from } \\
\text { asset price changes }\end{array}$ & -14.1 & -31.4 & -18.0 & -30.5 & -35.3 & -20.6 & -136.1 \\
\hline \multicolumn{8}{|l|}{ 3. Percentage decomposition } \\
\hline a. From asset price changes & -93.2 & -119.5 & -224.0 & -33.3 & -53.6 & 32.0 & -95.5 \\
\hline b. Residual & 193.2 & 219.5 & 324.0 & 133.3 & 153.6 & 68.0 & 195.5 \\
\hline \multicolumn{8}{|l|}{ E. Gini Coefficients } \\
\hline $\begin{array}{l}\text { 1. Actual Gini Coeff. in } \\
\text { start year }\end{array}$ & 0.799 & 0.828 & 0.826 & 0.834 & 0.866 & 0.877 & 0.799 \\
\hline $\begin{array}{l}\text { 2. New Gini coeff. From } \\
\text { asset price changes }\end{array}$ & 0.779 & 0.794 & 0.813 & 0.812 & 0.847 & 0.870 & 0.754 \\
\hline $\begin{array}{l}\text { 3. Change in the Gini coeff. } \\
\text { from asset price changes }\end{array}$ & -0.019 & -0.033 & -0.014 & -0.022 & -0.019 & -0.007 & -0.045 \\
\hline \multicolumn{8}{|c|}{$\begin{array}{l}\text { Source: author's computations from the SCF. Asset price } \\
\text { change data are from Table } 1 \text {. }\end{array}$} \\
\hline
\end{tabular}




\begin{tabular}{|lcccc|}
\hline $\begin{array}{l}\text { Table 9. Composition of Household Wealth by Race and Ethnicity: Consolidated } \\
\text { Accounts, 2019 }\end{array}$ & & & \\
(Percent of gross assets) & & Non-Hispanic & African- & \\
& All & Whites & Americans & Hispanics \\
Asset & 25.1 & 23.1 & 43.1 & 44.2 \\
\hline Principal residence & 10.4 & 9.6 & 12.4 & 11.8 \\
Other real estate & 20.1 & 21.7 & 11.8 & 12.5 \\
Unincorporated business equity & 6.7 & 6.8 & 7.0 & 8.1 \\
Liquid assets & 13.9 & 14.0 & 14.7 & 9.0 \\
Securities, directly or indirectly owned & 22.4 & 23.5 & 9.3 & 12.9 \\
Stocks, directly or indirectly owned & 1.3 & 1.3 & 1.6 & 1.4 \\
Miscellaneous assets & 100.0 & 100.0 & 100.0 & 100.0 \\
Total assets & & & & \\
& 8.6 & 7.8 & 18.2 & 19.6 \\
Debt on principal residence & 3.9 & 3.1 & 12.6 & 8.5 \\
All other debt & 12.5 & 10.9 & 30.8 & 28.1 \\
Total debt & & & & \\
\hline & & & & \\
Source: author's computations from the 2019 SCF. & & & \\
Also, see notes to Table 4. & & &
\end{tabular}




\begin{tabular}{|c|c|c|c|c|c|c|c|}
\hline & $\begin{array}{c}1983- \\
1989 \\
\end{array}$ & $\begin{array}{l}1989- \\
2001\end{array}$ & $\begin{array}{l}2001- \\
2007\end{array}$ & $\begin{array}{l}2007- \\
2010 \\
\end{array}$ & $\begin{array}{c}2010- \\
2016 \\
\end{array}$ & $\begin{array}{l}2016- \\
2019\end{array}$ & $\begin{array}{l}1983- \\
2019\end{array}$ \\
\hline \multicolumn{8}{|c|}{ A. Mean Net Worth of White Households } \\
\hline 1. Actual Percentage Change & 20.1 & 51.1 & 19.5 & -11.8 & 31.2 & -0.8 & 149.0 \\
\hline $\begin{array}{l}\text { 2. \%Change from asset price } \\
\text { changes }\end{array}$ & 18.8 & 23.5 & 5.5 & 10.8 & 11.0 & 0.6 & 96.7 \\
\hline 2a. Stocks & 0.9 & 1.6 & 0.4 & 0.2 & 1.1 & -0.3 & 6.2 \\
\hline 2b. Homes & 9.5 & 11.8 & 2.2 & 6.9 & 4.3 & 1.0 & 45.7 \\
\hline 2c. Businesses & 2.7 & 1.8 & 0.4 & 0.2 & 1.0 & -0.2 & 6.8 \\
\hline 2d. Liquid assets & -3.1 & -4.5 & -1.5 & -0.4 & -0.9 & -0.5 & -14.6 \\
\hline 2e. Non-home real estate & 3.9 & 4.7 & 0.8 & 2.6 & 1.6 & 0.4 & 17.5 \\
\hline 2f. Bonds & 1.6 & 3.2 & 0.8 & 0.4 & 2.3 & -0.6 & 13.5 \\
\hline 2g. Debt & 3.3 & 4.9 & 2.4 & 0.9 & 1.7 & 0.9 & 21.5 \\
\hline \multicolumn{8}{|l|}{ 3. Percentage decomposition } \\
\hline $\begin{array}{l}\text { a. Total effect from asset price } \\
\text { changes }\end{array}$ & 93.5 & 46.1 & 28.1 & -91.7 & 35.3 & -77.9 & 64.9 \\
\hline 2a. Stocks & 4.4 & 3.1 & 2.1 & -1.7 & 3.4 & 31.4 & 4.2 \\
\hline 2b. Homes & 47.2 & 23.1 & 11.3 & -58.9 & 13.7 & -117.0 & 30.7 \\
\hline 2c. Businesses & 13.4 & 3.4 & 1.8 & -1.9 & 3.2 & 28.1 & 4.6 \\
\hline 2d. Liquid assets & -15.5 & -8.7 & -7.8 & 3.7 & -3.0 & 66.5 & -9.8 \\
\hline 2e. Non-home real estate & 19.1 & 9.3 & 4.0 & -21.9 & 5.2 & -44.8 & 11.7 \\
\hline 2f. Bonds & 8.2 & 6.2 & 4.3 & -3.6 & 7.4 & 68.7 & 9.1 \\
\hline 2g. Debt & 16.6 & 9.6 & 12.4 & -7.4 & 5.5 & -110.8 & 14.4 \\
\hline \multicolumn{8}{|c|}{ B. Mean Net Worth of Black Households } \\
\hline 1. \%Change & 7.0 & 28.4 & 57.9 & -32.7 & 31.8 & -5.9 & 81.0 \\
\hline $\begin{array}{l}\text { 2. \%Change from asset price } \\
\text { changes }\end{array}$ & 27.4 & 43.9 & 13.4 & 24.1 & 21.2 & 5.1 & 193.7 \\
\hline 2a. Stocks & 0.3 & 1.0 & 0.2 & 0.1 & 0.6 & -0.1 & 3.4 \\
\hline 2b. Homes & 15.8 & 24.9 & 5.1 & 16.7 & 10.6 & 2.4 & 101.4 \\
\hline 2c. Businesses & 1.3 & 0.4 & 0.1 & 0.1 & 0.6 & -0.2 & 3.3 \\
\hline 2d. Liquid assets & -2.9 & -6.3 & -2.7 & -0.7 & -1.3 & -0.7 & -19.8 \\
\hline 2e. Non-home real estate & 6.0 & 7.2 & 1.3 & 4.7 & 3.1 & 0.7 & 30.1 \\
\hline 2f. Bonds & 0.6 & 2.1 & 0.5 & 0.2 & 1.3 & -0.3 & 7.5 \\
\hline 2g. Debt & 6.2 & 14.5 & 8.8 & 3.0 & 6.2 & 3.4 & 67.8 \\
\hline \multicolumn{8}{|l|}{ 3. Percentage decomposition } \\
\hline $\begin{array}{l}\text { a. Total effect from asset price } \\
\text { changes }\end{array}$ & 392.6 & 154.8 & 23.2 & -73.8 & 66.7 & -86.4 & 239.3 \\
\hline 2a. Stocks & 5.0 & 3.7 & 0.4 & -0.3 & 1.9 & 2.2 & 4.2 \\
\hline 2b. Homes & 226.5 & 87.7 & 8.8 & -51.2 & 33.5 & -39.7 & 125.3 \\
\hline 2c. Businesses & 18.8 & 1.5 & 0.2 & -0.3 & 1.8 & 3.0 & 4.1 \\
\hline 2d. Liquid assets & -41.2 & -22.0 & -4.7 & 2.0 & -4.1 & 11.8 & -24.5 \\
\hline 2e. Non-home real estate & 85.9 & 25.4 & 2.3 & -14.2 & 9.9 & -11.0 & 37.2 \\
\hline 2f. Bonds & 9.3 & 7.4 & 0.9 & -0.7 & 4.2 & 4.8 & 9.2 \\
\hline 2g. Debt & 88.3 & 51.2 & 15.2 & -9.1 & 19.5 & -57.5 & 83.8 \\
\hline \multicolumn{8}{|c|}{ C. Mean Net Worth of Hispanic Households } \\
\hline 1. Actual Percentage Change & 21.6 & 57.8 & 81.6 & -48.1 & 61.6 & -1.8 & 187.2 \\
\hline
\end{tabular}




\begin{tabular}{|c|c|c|c|c|c|c|c|}
\hline $\begin{array}{l}\text { 2. \%Change from asset price } \\
\text { changes }\end{array}$ & 36.6 & 49.2 & 13.3 & 25.1 & 22.5 & 4.9 & 212.1 \\
\hline 2a. Stocks & 0.2 & 0.7 & 0.2 & 0.1 & 0.5 & -0.1 & 2.9 \\
\hline 2b. Homes & 22.2 & 27.3 & 4.9 & 17.4 & 11.8 & 2.4 & 111.6 \\
\hline 2c. Businesses & 1.0 & 1.3 & 0.4 & 0.2 & 1.0 & -0.2 & 5.5 \\
\hline 2d. Liquid assets & -3.0 & -5.2 & -1.6 & -0.4 & -0.8 & -0.6 & -14.7 \\
\hline 2e. Non-home real estate & 5.6 & 6.4 & 1.3 & 4.6 & 2.4 & 0.6 & 27.2 \\
\hline 2f. Bonds & 0.4 & 1.5 & 0.4 & 0.2 & 1.1 & -0.3 & 6.4 \\
\hline 2g. Debt & 10.3 & 17.2 & 7.8 & 3.1 & 6.4 & 3.1 & 73.2 \\
\hline \multicolumn{8}{|l|}{ 3. Percentage decomposition } \\
\hline $\begin{array}{l}\text { a. Total effect from asset price } \\
\text { changes }\end{array}$ & 169.2 & 85.2 & 16.3 & -52.2 & 36.5 & -273.3 & 113.3 \\
\hline 2a. Stocks & 0.9 & 1.3 & 0.2 & -0.2 & 0.8 & 8.1 & 1.6 \\
\hline 2b. Homes & 102.6 & 47.2 & 6.0 & -36.1 & 19.2 & -136.5 & 59.6 \\
\hline 2c. Businesses & 4.4 & 2.2 & 0.4 & -0.4 & 1.7 & 11.3 & 3.0 \\
\hline 2d. Liquid assets & -13.9 & -8.9 & -1.9 & 0.8 & -1.3 & 33.0 & -7.8 \\
\hline 2e. Non-home real estate & 25.8 & 11.1 & 1.5 & -9.5 & 3.9 & -34.4 & 14.5 \\
\hline 2f. Bonds & 1.8 & 2.5 & 0.5 & -0.4 & 1.8 & 17.7 & 3.4 \\
\hline 2g. Debt & 47.5 & 29.8 & 9.5 & -6.4 & 10.4 & -172.5 & 39.1 \\
\hline \multicolumn{8}{|c|}{ D. Ratio of the Mean Wealth of Black Households to White Households } \\
\hline 1. Change in the actual ratio & -0.021 & -0.025 & 0.046 & $\overline{-0.045}$ & 0.001 & -0.007 & -0.051 \\
\hline $\begin{array}{l}\text { 2. Change in the ratio from } \\
\text { asset price changes }\end{array}$ & 0.014 & 0.028 & 0.011 & 0.023 & 0.013 & 0.006 & 0.093 \\
\hline \multicolumn{8}{|l|}{ 3. Percentage decomposition } \\
\hline a. From asset price changes & -66.0 & -109.9 & 23.4 & -50.6 & 2063.0 & -86.4 & -180.7 \\
\hline b. Residual & 166.0 & 209.9 & 76.6 & 150.6 & -1963.0 & 186.4 & 280.7 \\
\hline \multicolumn{8}{|c|}{ E. Ratio of the Mean Wealth of Hispanic Households to White } \\
\hline \multicolumn{8}{|c|}{ Households } \\
\hline 1. Change in the actual ratio & 0.002 & 0.007 & 0.089 & -0.107 & 0.036 & -0.002 & $\mathbf{0 . 0 2 5}$ \\
\hline $\begin{array}{l}\text { 2. Change in the ratio from } \\
\text { asset price changes }\end{array}$ & -0.001 & 0.031 & 0.042 & 0.107 & 0.026 & 0.053 & $\mathbf{0 . 0 7 0}$ \\
\hline \multicolumn{8}{|l|}{ 3. Percentage decomposition } \\
\hline a. From asset price changes & -63.7 & 426.1 & 47.3 & -99.4 & 73.1 & -2854.3 & 279.6 \\
\hline b. Residual & 163.7 & -326.1 & 52.7 & 199.4 & 26.9 & 2954.3 & -179.6 \\
\hline
\end{tabular}




\begin{tabular}{|c|c|c|c|c|c|c|c|c|}
\hline \multicolumn{9}{|c|}{ Table 11. Age-Wealth Profiles, 1983-2019 } \\
\hline Age & 1983 & 1989 & 2001 & 2004 & 2007 & 2010 & 2016 & 2019 \\
\hline \multicolumn{9}{|c|}{ A. Mean Net Worth (Ratio to Overall Mean) } \\
\hline Overall & 1.00 & 1.00 & 1.00 & 1.00 & 1.00 & 1.00 & 1.00 & 1.00 \\
\hline Under 35 & 0.21 & 0.29 & 0.19 & 0.14 & 0.17 & 0.11 & 0.09 & 0.08 \\
\hline $35-44$ & 0.71 & 0.72 & 0.64 & 0.65 & 0.58 & 0.42 & 0.40 & 0.57 \\
\hline $45-54$ & 1.53 & 1.50 & 1.25 & 1.21 & 1.19 & 1.14 & 1.05 & 1.11 \\
\hline $55-64$ & 1.67 & 1.58 & 1.86 & 1.91 & 1.69 & 1.80 & 1.70 & 1.59 \\
\hline $65-74$ & 1.93 & 1.61 & 1.72 & 1.57 & 1.86 & 1.73 & 1.55 & 1.64 \\
\hline 75 \& over & 1.05 & 1.26 & 1.20 & 1.19 & 1.16 & 1.35 & 1.57 & 1.30 \\
\hline
\end{tabular}

\begin{tabular}{|c|c|c|c|c|c|c|c|}
\hline \multicolumn{8}{|c|}{$\begin{array}{l}\text { Table 12. Composition of Household Wealth by Age Group: } \\
\text { Consolidated Accounts, } 2019 \\
\text { (Percent of gross assets) }\end{array}$} \\
\hline Asset & All & Under 35 & $\begin{array}{c}35- \\
44 \\
\end{array}$ & $\begin{array}{c}45- \\
54 \\
\end{array}$ & $\begin{array}{c}55- \\
64 \\
\end{array}$ & $\begin{array}{c}65- \\
74 \\
\end{array}$ & $\begin{array}{l}75 \& \\
\text { over }\end{array}$ \\
\hline Principal residence & 25.1 & 56.9 & 36.3 & 29.4 & 22.5 & 22.1 & 24.4 \\
\hline Other real estate & 10.4 & 4.3 & 9.5 & 9.3 & 9.5 & 9.6 & 10.3 \\
\hline Unincorporated business equity & 20.1 & 14.4 & 24.8 & 21.9 & 22.7 & 17.7 & 12.9 \\
\hline Liquid assets & 6.7 & 9.0 & 5.8 & 6.6 & 6.4 & 6.9 & 8.6 \\
\hline Securities, directly or indirectly owned & 13.9 & 6.0 & 7.3 & 11.4 & 14.8 & 15.0 & 13.7 \\
\hline Stocks, directly or indirectly owned & 22.4 & 8.4 & 15.7 & 20.2 & 22.8 & 27.0 & 28.0 \\
\hline Miscellaneous assets & 1.3 & 0.9 & 0.5 & 1.1 & 1.4 & 1.6 & 2.1 \\
\hline Total assets & 100.0 & 100.0 & 100.0 & 100.0 & 100.0 & 100.0 & 100.0 \\
\hline Debt on principal residence & 8.6 & 36.6 & 20.8 & 11.6 & 6.1 & 4.2 & 3.3 \\
\hline All other debt & 3.9 & 20.1 & 7.6 & 4.3 & 2.9 & 1.6 & 1.3 \\
\hline Total debt & 12.5 & 56.7 & 28.4 & 15.9 & 8.9 & 5.8 & 4.6 \\
\hline
\end{tabular}




\begin{tabular}{|c|c|c|c|c|c|c|c|}
\hline & $\begin{array}{l}1983- \\
1989\end{array}$ & $\begin{array}{c}1989- \\
2001 \\
\end{array}$ & $\begin{array}{l}2001- \\
2007\end{array}$ & $\begin{array}{l}2007- \\
2010\end{array}$ & $\begin{array}{c}2010- \\
2016 \\
\end{array}$ & $\begin{array}{l}2016- \\
2019 \\
\end{array}$ & $\begin{array}{l}1983- \\
2019 \\
\end{array}$ \\
\hline \multicolumn{8}{|l|}{ A. Age Group Under 35} \\
\hline 1. Change in the actual ratio & 0.076 & -0.091 & -0.025 & -0.061 & -0.018 & -0.006 & -0.125 \\
\hline $\begin{array}{l}\text { 2. Change in the ratio from } \\
\text { asset price changes }\end{array}$ & 0.013 & 0.057 & 0.023 & 0.030 & 0.021 & 0.008 & 0.107 \\
\hline \multicolumn{8}{|l|}{ B. Age Group 35-44 } \\
\hline 1. Change in the actual ratio & 0.018 & -0.080 & -0.068 & -0.158 & -0.020 & 0.176 & -0.131 \\
\hline $\begin{array}{l}\text { 2. Change in the ratio from } \\
\text { asset price changes }\end{array}$ & 0.025 & 0.083 & 0.028 & 0.040 & 0.032 & 0.011 & 0.062 \\
\hline \multicolumn{8}{|l|}{ C. Age Group 45-54 } \\
\hline 1. Change in the actual ratio & -0.030 & -0.244 & -0.061 & -0.047 & -0.097 & 0.063 & -0.415 \\
\hline $\begin{array}{l}\text { 2. Change in the ratio from } \\
\text { asset price changes }\end{array}$ & 0.013 & 0.020 & 0.004 & 0.005 & 0.012 & 0.005 & -0.015 \\
\hline \multicolumn{8}{|l|}{ D. Age Group 55-64 } \\
\hline 1. Change in the actual ratio & -0.088 & 0.278 & -0.173 & 0.116 & -0.099 & -0.114 & -0.080 \\
\hline $\begin{array}{l}\text { 2. Change in the ratio from } \\
\text { asset price changes }\end{array}$ & -0.015 & -0.051 & -0.023 & -0.030 & -0.024 & -0.009 & -0.121 \\
\hline \multicolumn{8}{|l|}{ E. Age Group 65-74 } \\
\hline 1. Change in the actual ratio & -0.323 & 0.106 & 0.144 & -0.132 & -0.176 & 0.093 & -0.288 \\
\hline $\begin{array}{l}\text { 2. Change in the ratio from } \\
\text { asset price changes }\end{array}$ & -0.056 & -0.113 & -0.034 & -0.041 & -0.033 & -0.012 & -0.153 \\
\hline \multicolumn{8}{|l|}{ F. Age Group 75 and over } \\
\hline 1. Change in the actual ratio & 0.212 & -0.065 & -0.037 & 0.195 & 0.217 & -0.273 & 0.247 \\
\hline $\begin{array}{l}\text { 2. Change in the ratio from } \\
\text { asset price changes }\end{array}$ & -0.059 & -0.131 & -0.041 & -0.026 & -0.032 & -0.013 & -0.156 \\
\hline
\end{tabular}




\section{Table 14. Percentage Change of Real Asset Values over Period: Variants}

\section{Bond Value}

a) 10-year bond rate ${ }^{\mathrm{a}}$ : Base Case

b) 20-year bond rate ${ }^{b}$

c) 30-year bond rate ${ }^{c}$

2. Present Value of Future Profits

a) 10-year bond rate: Base Case

b) 20-year bond rate ${ }^{\mathrm{b}}$

c) 30-year bond rate ${ }^{\mathrm{c}}$

\section{Home Prices}

a) 30-year mortgage ${ }^{\mathrm{d}}$ :

Base Case

b) 10-year mortgage ${ }^{e}$

4. Liquid Assets

a) No interest ${ }^{\mathrm{f}}$ : Base Case

b) Federal funds rate ${ }^{\mathrm{g}}$

Asset values are deflated by the CPI-U-RS.

a. Based on US Treasury Securities (Constant Maturity): 10-year real bond rate for 10-year period

b. Based on US Treasury Securities (Constant Maturity): 20-year real bond rate for 20-year period

c. Based on US Treasury Securities (Constant Maturity): 30-year real bond rate for 30-year period d. Based on 30-Year Fixed Rate Mortgage Average in the United States, Percent, Weekly, Not Seasonally Adjusted

Equivalent monthly payments: 30 -year mortgage and $20 \%$ downpayment e. Based on 10-Year Fixed Rate Mortgage Average in the United States, Percent, Weekly, Not Seasonally Adjusted

Equivalent monthly payments: 10-year mortgage and $20 \%$ downpayment f. It is assumed that no interest accrues over time.

g. It is assumed that interest at the Federal funds rate accrues over time. 


\section{Table 15. Changes in Inequality under Alternative Scenarios}

\begin{tabular}{|c|c|c|c|c|c|c|c|}
\hline & $\begin{array}{c}1983- \\
1989\end{array}$ & $\begin{array}{l}1989- \\
2001\end{array}$ & $\begin{array}{l}2001- \\
2007\end{array}$ & $\begin{array}{l}2007- \\
2010\end{array}$ & $\begin{array}{l}2010- \\
2016\end{array}$ & $\begin{array}{l}2016- \\
2019\end{array}$ & $\begin{array}{l}1983- \\
2019\end{array}$ \\
\hline \multicolumn{8}{|c|}{ A. Ratio of the Mean Wealth of the Top One Percent to Median Wealth } \\
\hline \multirow{2}{*}{\multicolumn{8}{|c|}{$\begin{array}{l}\text { 2. Change in the ratio from } \\
\text { asset price changes }\end{array}$}} \\
\hline & & & & & & & \\
\hline A. Base Case & -14.1 & -31.4 & -18.0 & -30.5 & -35.3 & -20.6 & -136.1 \\
\hline B. Scenario I & -7.0 & -30.0 & -14.9 & -32.8 & -27.2 & -23.4 & -116.1 \\
\hline C. Scenario II & -2.6 & -26.6 & -13.5 & -35.9 & -22.8 & -30.1 & -101.6 \\
\hline D. Scenario III & -5.1 & -19.0 & -13.4 & -15.6 & -20.2 & -9.0 & -101.1 \\
\hline E. Scenario IV & -22.9 & -38.1 & -20.3 & -30.7 & -35.4 & -21.8 & -141.0 \\
\hline F. Scenario V & 7.5 & -13.7 & -8.8 & -21.2 & -7.4 & -18.8 & -55.1 \\
\hline \multicolumn{8}{|c|}{ B. Change in the Gini coeff. from asset price changes } \\
\hline A. Base Case & -0.019 & -0.033 & -0.014 & -0.022 & -0.019 & -0.007 & -0.045 \\
\hline B. Scenario I & -0.013 & -0.032 & -0.012 & -0.023 & -0.016 & -0.007 & -0.034 \\
\hline C. Scenario II & -0.009 & -0.030 & -0.011 & -0.025 & -0.015 & -0.009 & -0.026 \\
\hline D. Scenario III & -0.011 & -0.023 & -0.011 & -0.011 & -0.014 & -0.004 & -0.020 \\
\hline E. Scenario IV & -0.028 & -0.039 & -0.016 & -0.022 & -0.019 & -0.007 & -0.071 \\
\hline F. Scenario V & 0.000 & -0.019 & -0.008 & -0.014 & -0.010 & -0.005 & 0.003 \\
\hline
\end{tabular}

Source: author's computations from the SCF. Asset price change data are from Table 1.

A. Base Case uses:

(1) US Treasury Securities (Constant Maturity): 10-year real bond rate for 10-year period

(2) 30-Year Fixed Rate Mortgage Average in the United States, Weekly, Not Seasonally Adjusted Equivalent monthly payments: 30 -year mortgage and $20 \%$ down payment

(3) It is assumed that no interest accrues over time on liquid assets.

B. Scenario I uses:

(1) US Treasury Securities (Constant Maturity): 20-year real bond rate for 20-year period

(2) 30-Year Fixed Rate Mortgage Average in the United States, Weekly, Not Seasonally Adjusted

(3) It is assumed that no interest accrues over time on liquid assets.

C. Scenario II uses:

(1) US Treasury Securities (Constant Maturity): 30-year real bond rate for 30-year period

(2) 30-Year Fixed Rate Mortgage Average in the United States, Weekly, Not Seasonally Adjusted

(3) It is assumed that no interest accrues over time on liquid assets.

D. Scenario III uses:

(1) US Treasury Securities (Constant Maturity): 10-year real bond rate for 10-year period

(2) 10-Year Fixed Rate Mortgage Average in the United States, Weekly, Not Seasonally Adjusted Equivalent monthly payments: 10 -year mortgage and $20 \%$ down payment

(3) It is assumed that no interest accrues over time on liquid assets.

E. Scenario IV uses:

(1) US Treasury Securities (Constant Maturity): 10-year real bond rate for 10-year period

(2) 30-Year Fixed Rate Mortgage Average in the United States, Weekly, Not Seasonally Adjusted

(3) It is assumed that interest at the Federal funds rate accrues over time on liquid assets.

F. Scenario V uses:

(1) US Treasury Securities (Constant Maturity): 30-year real bond rate for 30-year period

(2) 10-Year Fixed Rate Mortgage Average in the United States, Weekly, Not Seasonally Adjusted

(3) It is assumed that no interest accrues over time on liquid assets. 


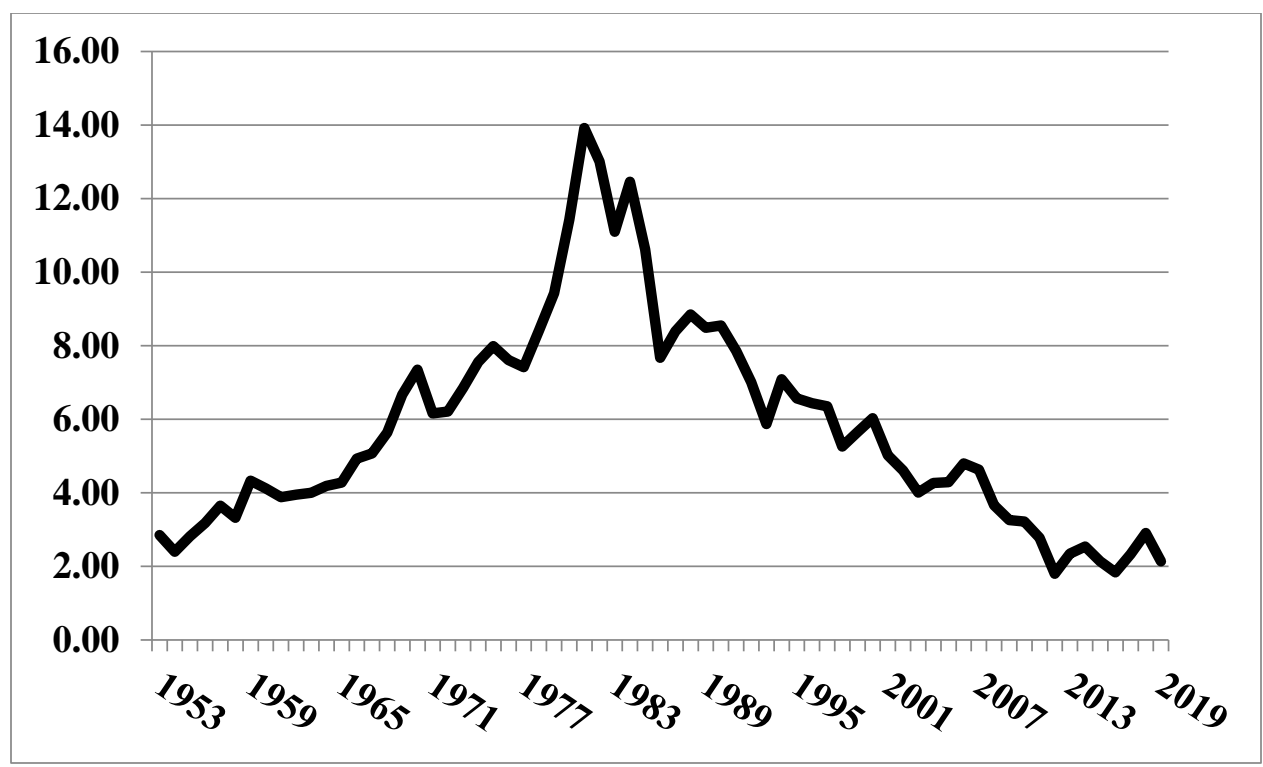

Figure 1. 10-Year Constant Maturity Treasury Bond Nominal Rates, 1953-2019 [Source: Economic Report of the President, 2020, Table B-42, p. 414]

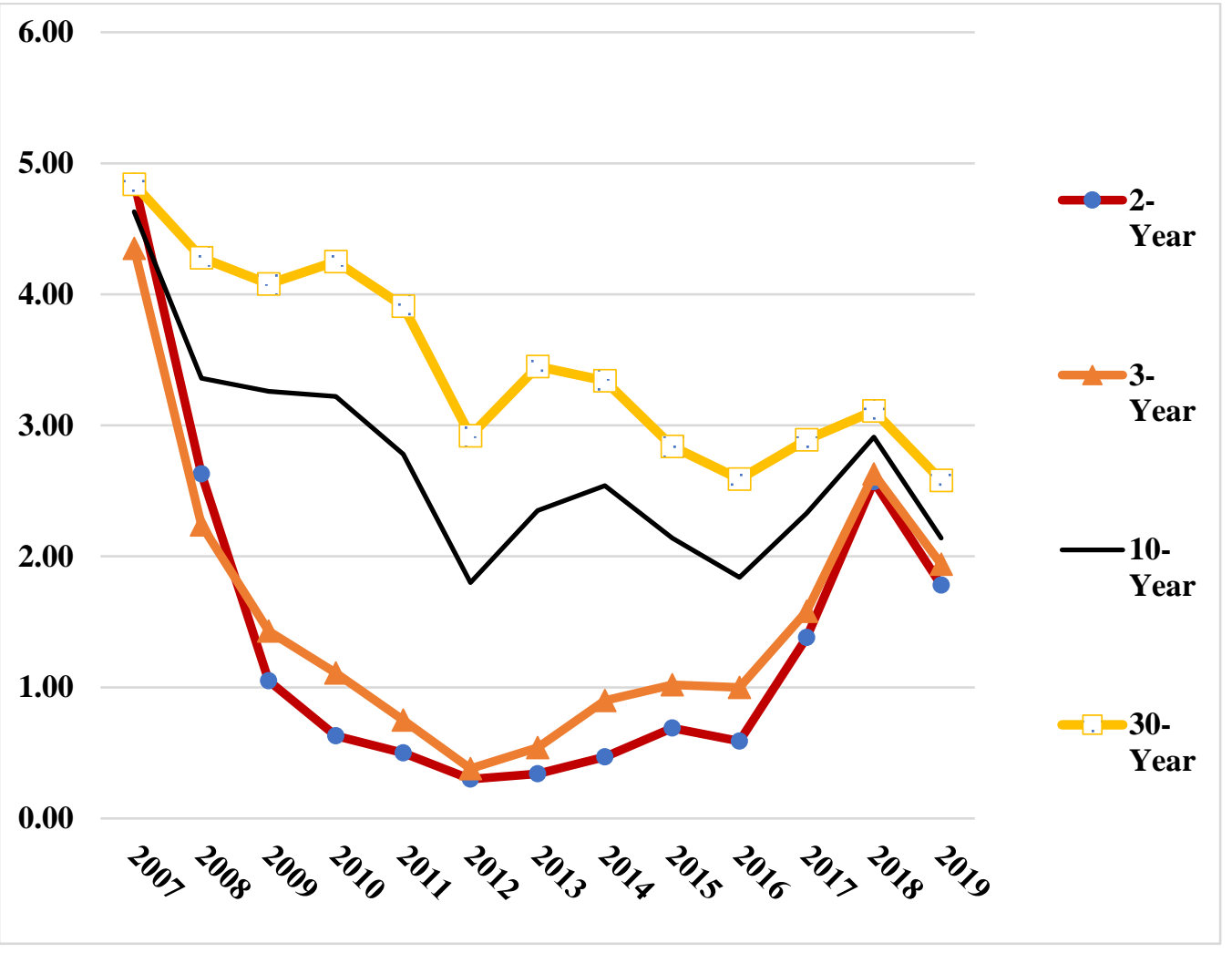

Figure 2. US Treasury Securities Yields, Constant Maturity, Percent per Annum, 2007-2019 [Source: Economic Report of the President, 2020, Table B-42, p. 414] 


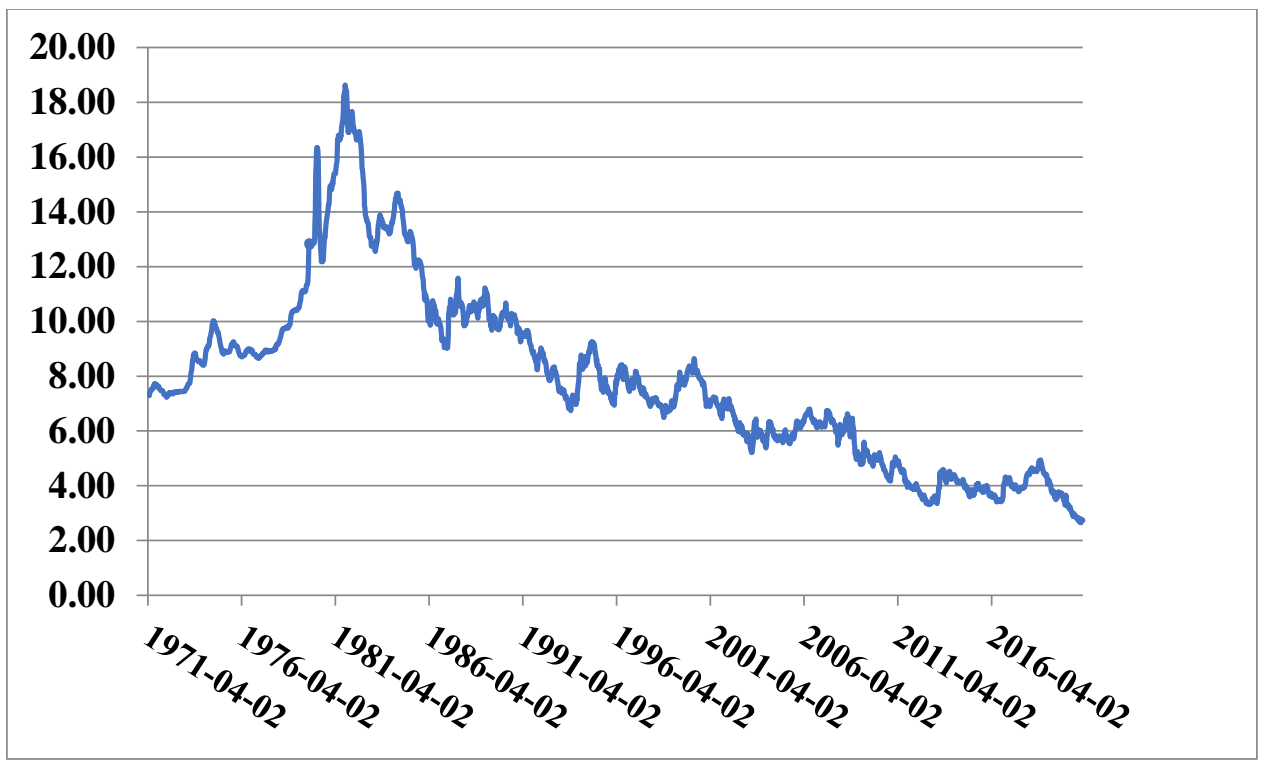

Figure 3. 30-Year Fixed Rate Mortgage Average, 1971-2021

[Source: Freddie Mac, 30-Year Fixed Rate Mortgage Average in the United States [MORTGAGE30US], retrieved from FRED, Federal Reserve Bank of St. Louis; https://fred.stlouisfed.org/series/MORTGAGE30US, February 11, 2021.]

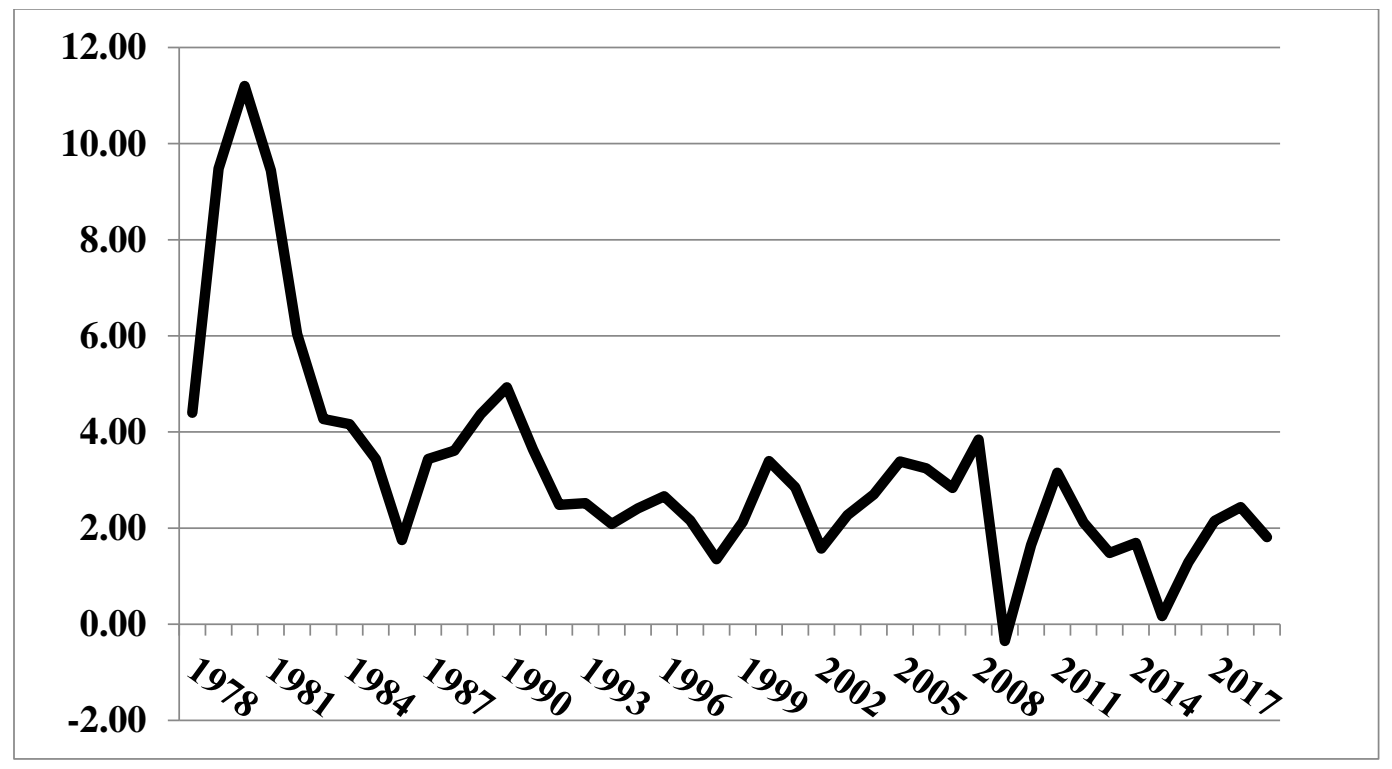

Figure 4. Annual Percentage Change of CPI-U-RS, 1978-2019

[Source: Bureau of Labor Statistics at https://www.bls.gov/cpi/research-series/home.htm] 


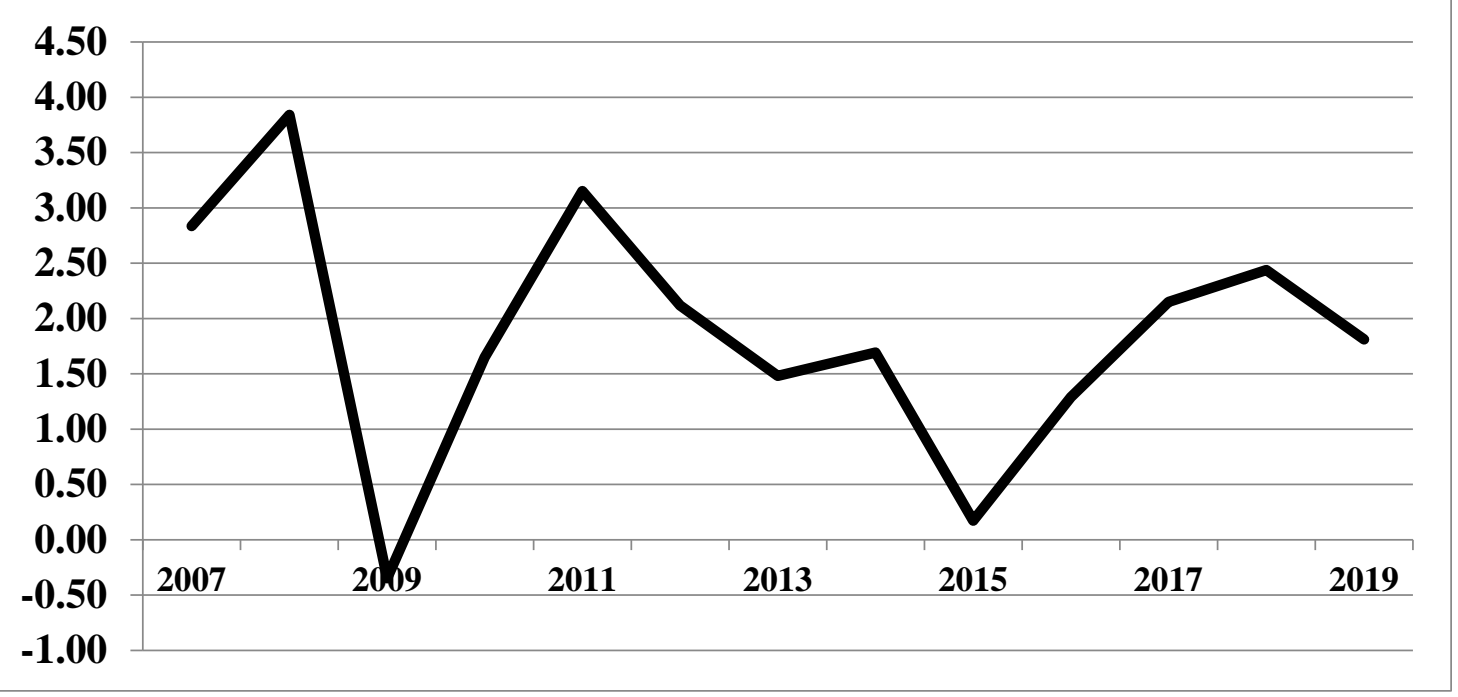

Figure 5. Annual Percentage Change of CPI-U-RS, 2007-2019

[Source: Bureau of Labor Statistics at https://www.bls.gov/cpi/research-series/home.htm]

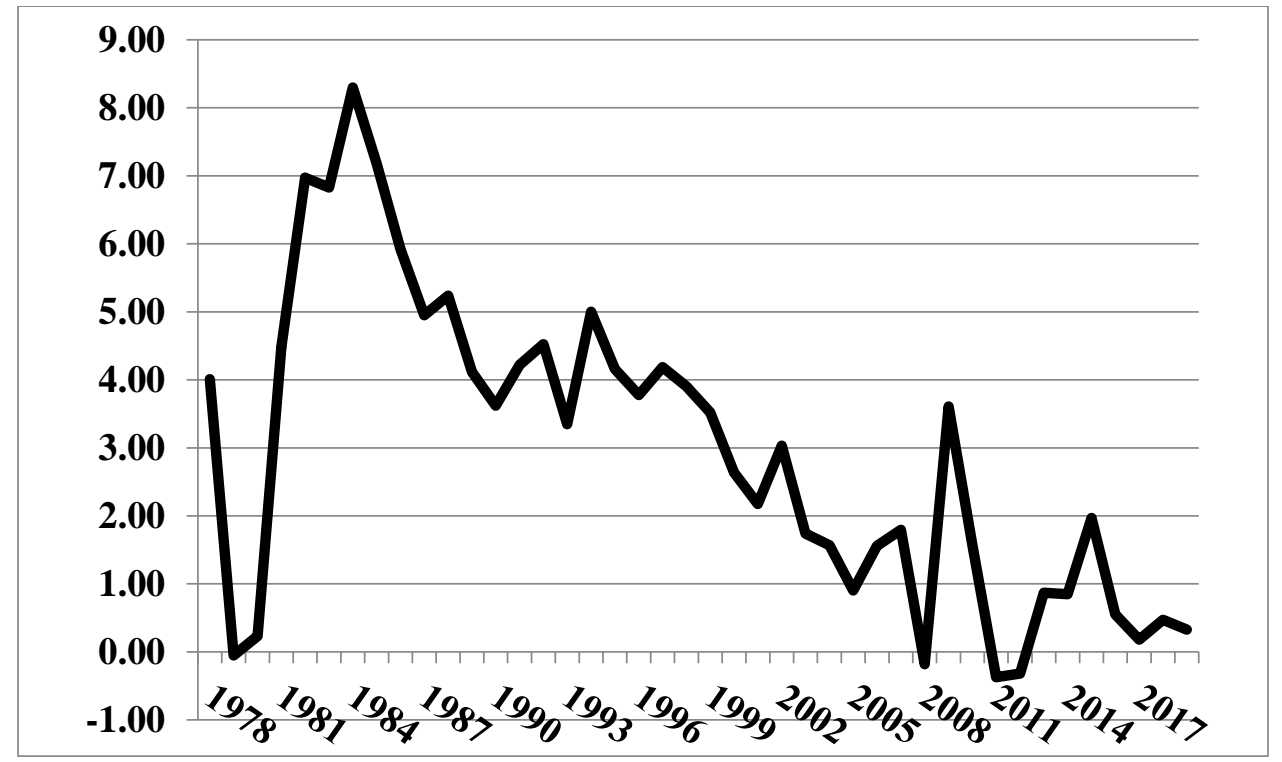

Figure 6. 10-Year Constant Maturity Real Treasury Bond Rates, 1978-2019 [Source: Economic Report of the President, 2020, Table B-42, p. 414] 


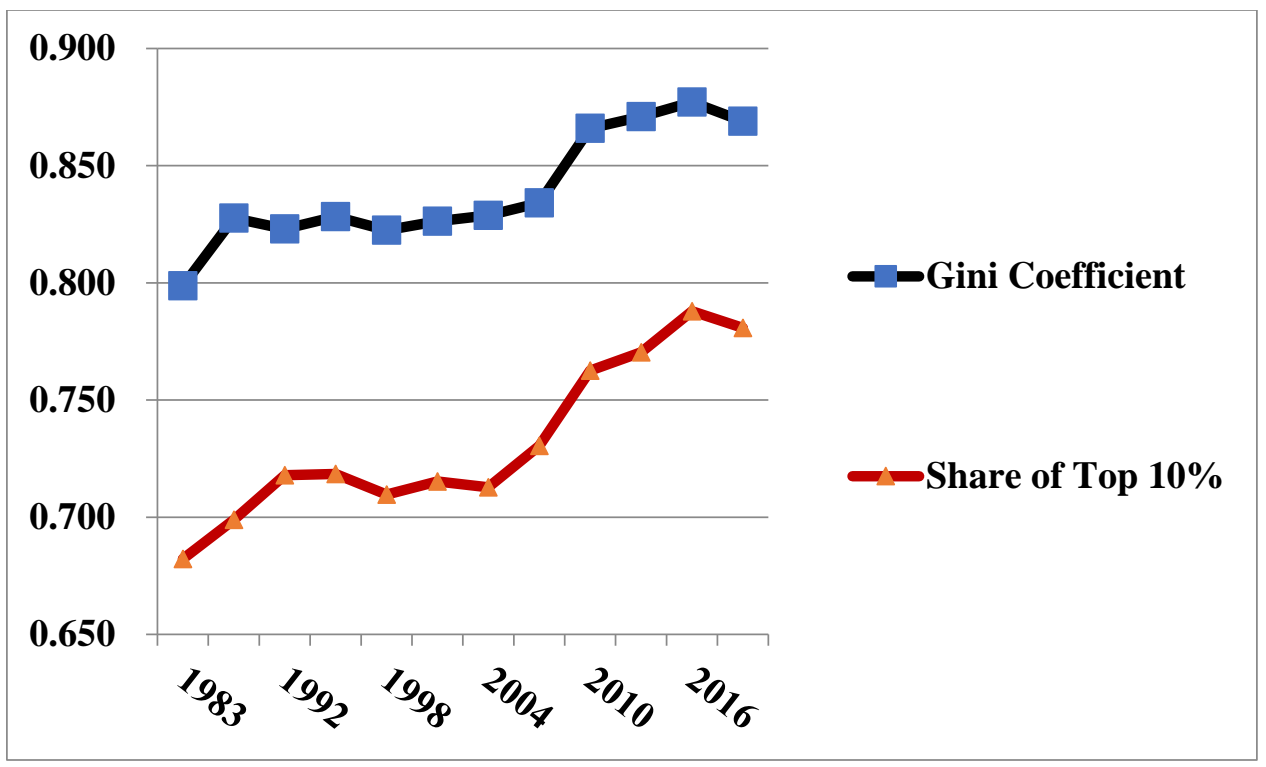

Figure 7. Household Wealth Inequality, 1983-2019

Source: Author's computations from the Survey of Consumer Finances.]

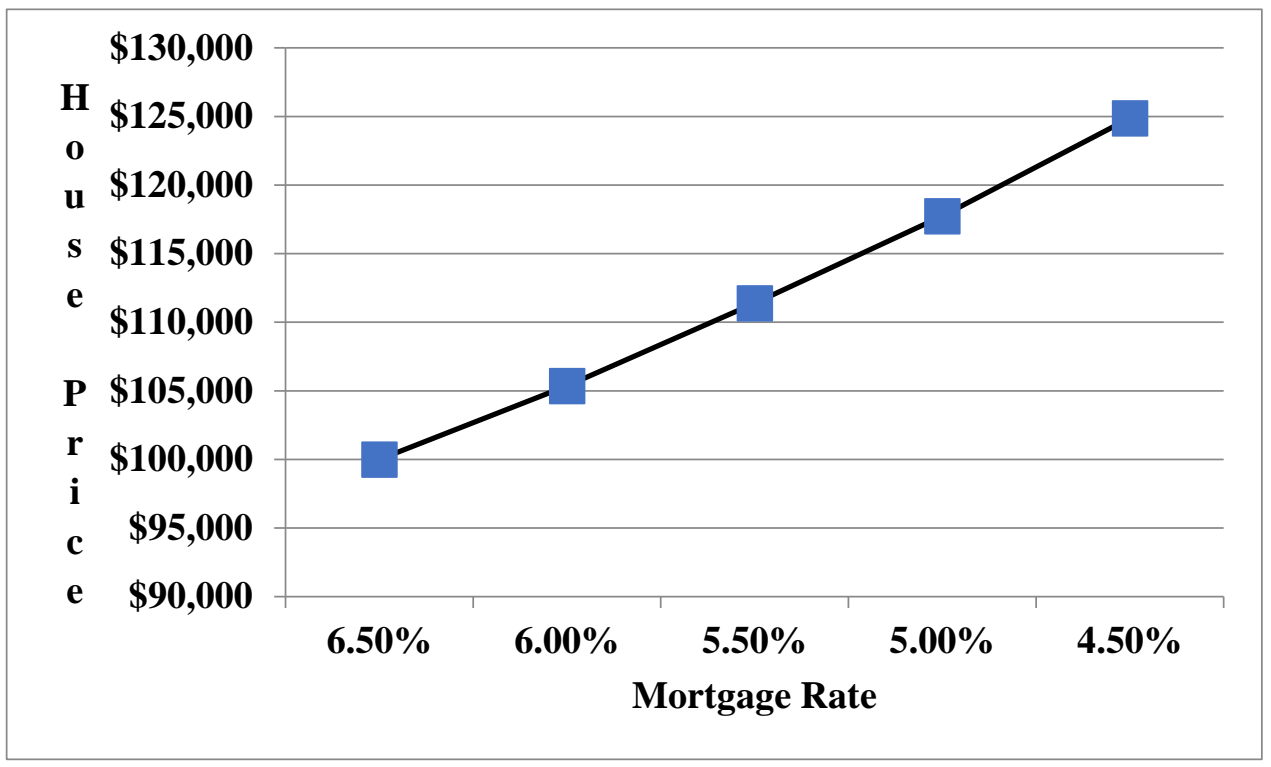

Figure 8. Equivalent monthly payments: House price versus mortgage rate. [based on a 30-year fixed rate mortgage with 20 percent down-payment and monthly payments] 


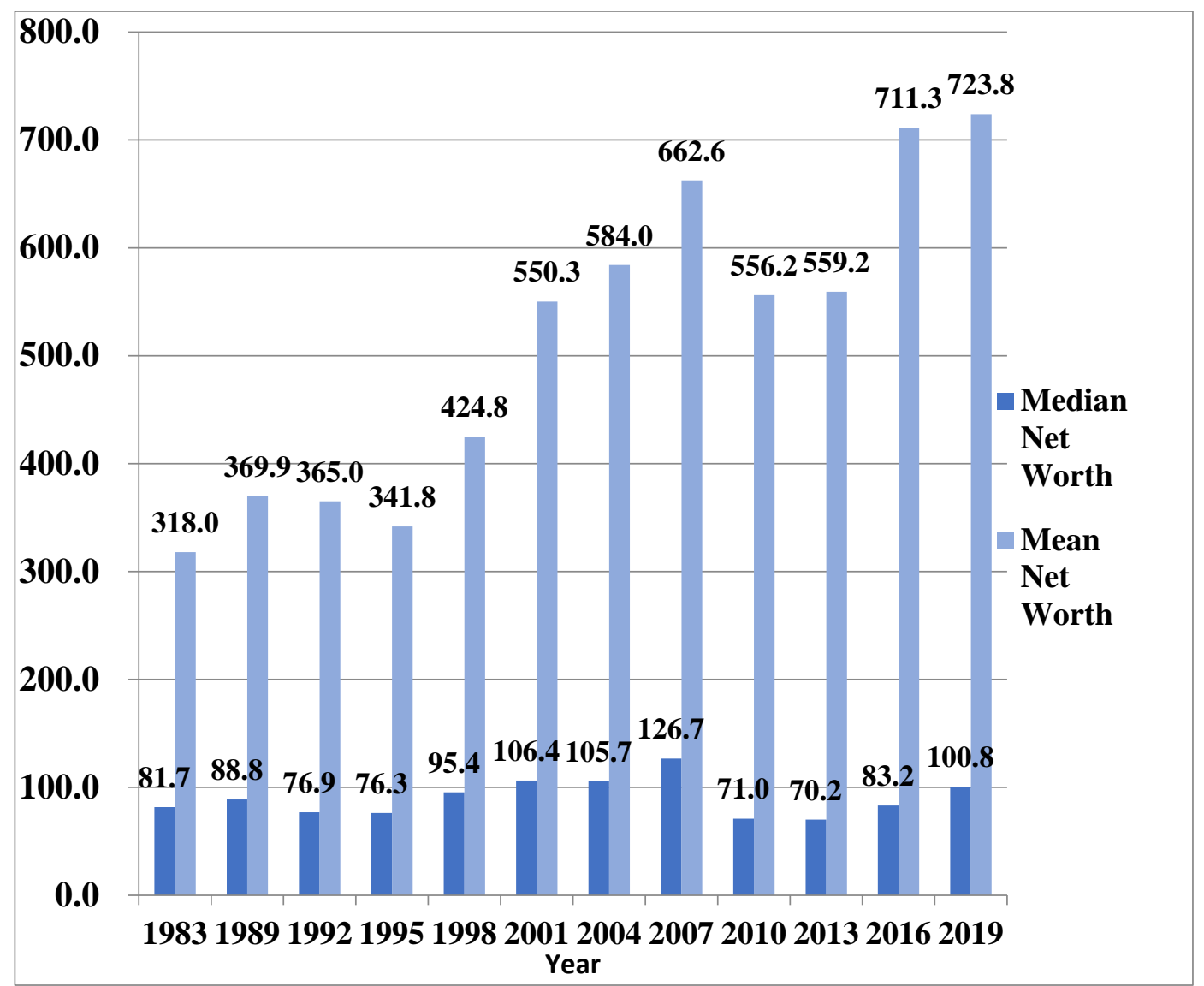

Figure 9. Median and Mean Net Worth (in 1000s, 2019 dollars)

[Source: Author's computations from the Survey of Consumer Finances] 


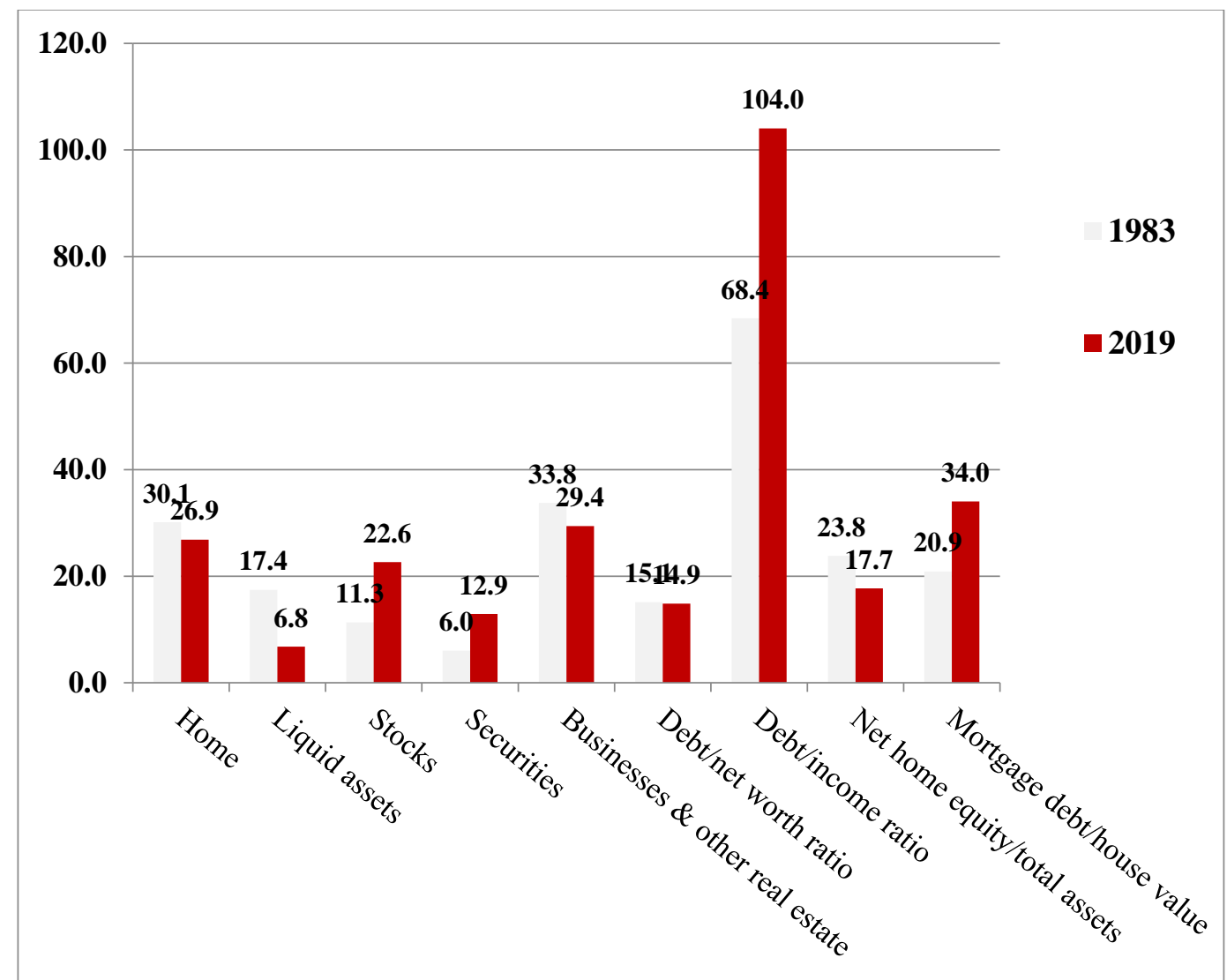

Figure 10 Composition of Household Wealth, 1983 and 2019, Consolidated Accounts (percent of gross assets)

[Source: Author's computations from the Survey of Consumer Finances] 


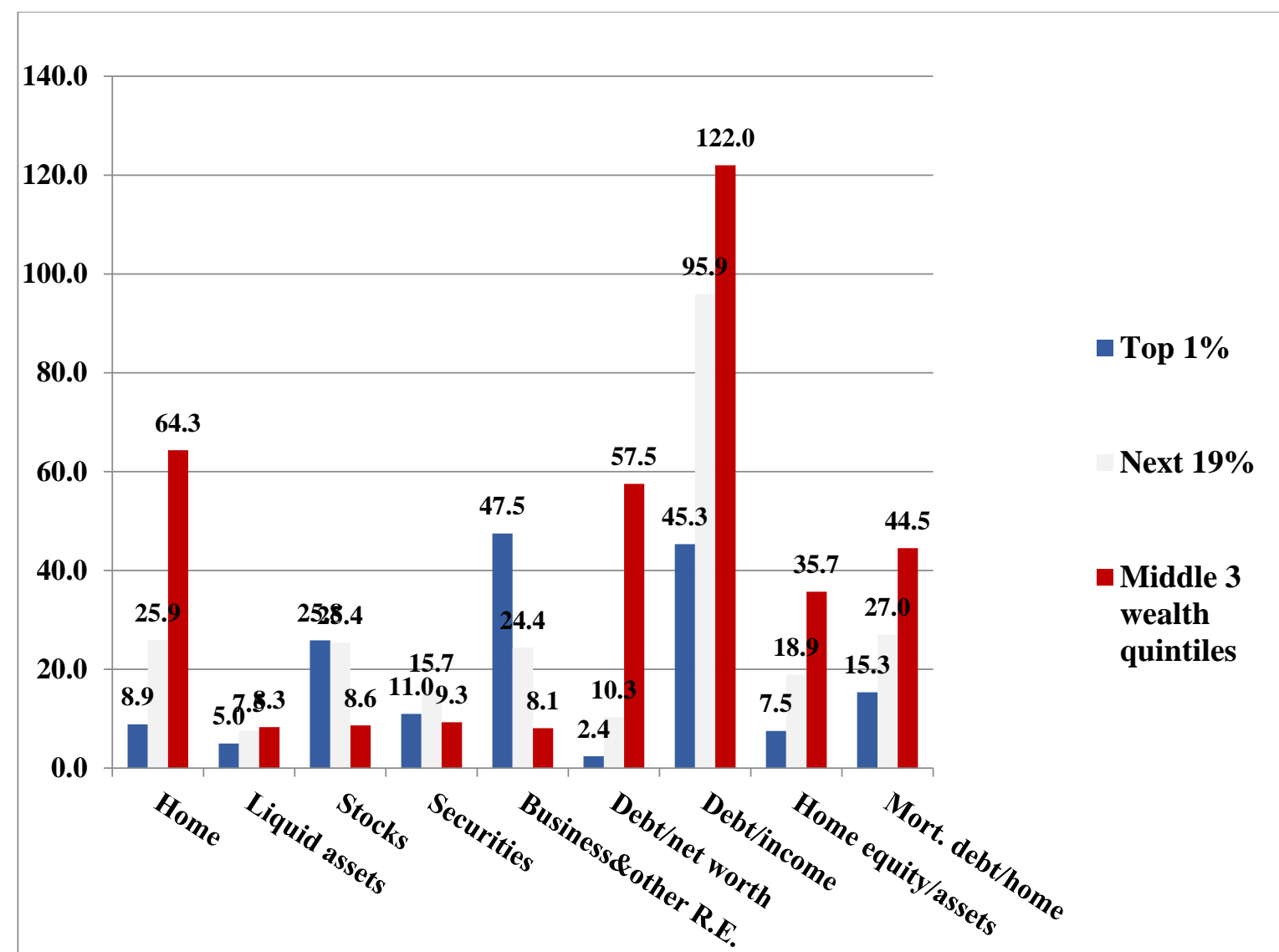

Figure 11. Composition of Household Wealth by Wealth Class, 2019: Consolidated Accounts (percent of gross assets)

[Source: Author's computations from the 2019 SCF]

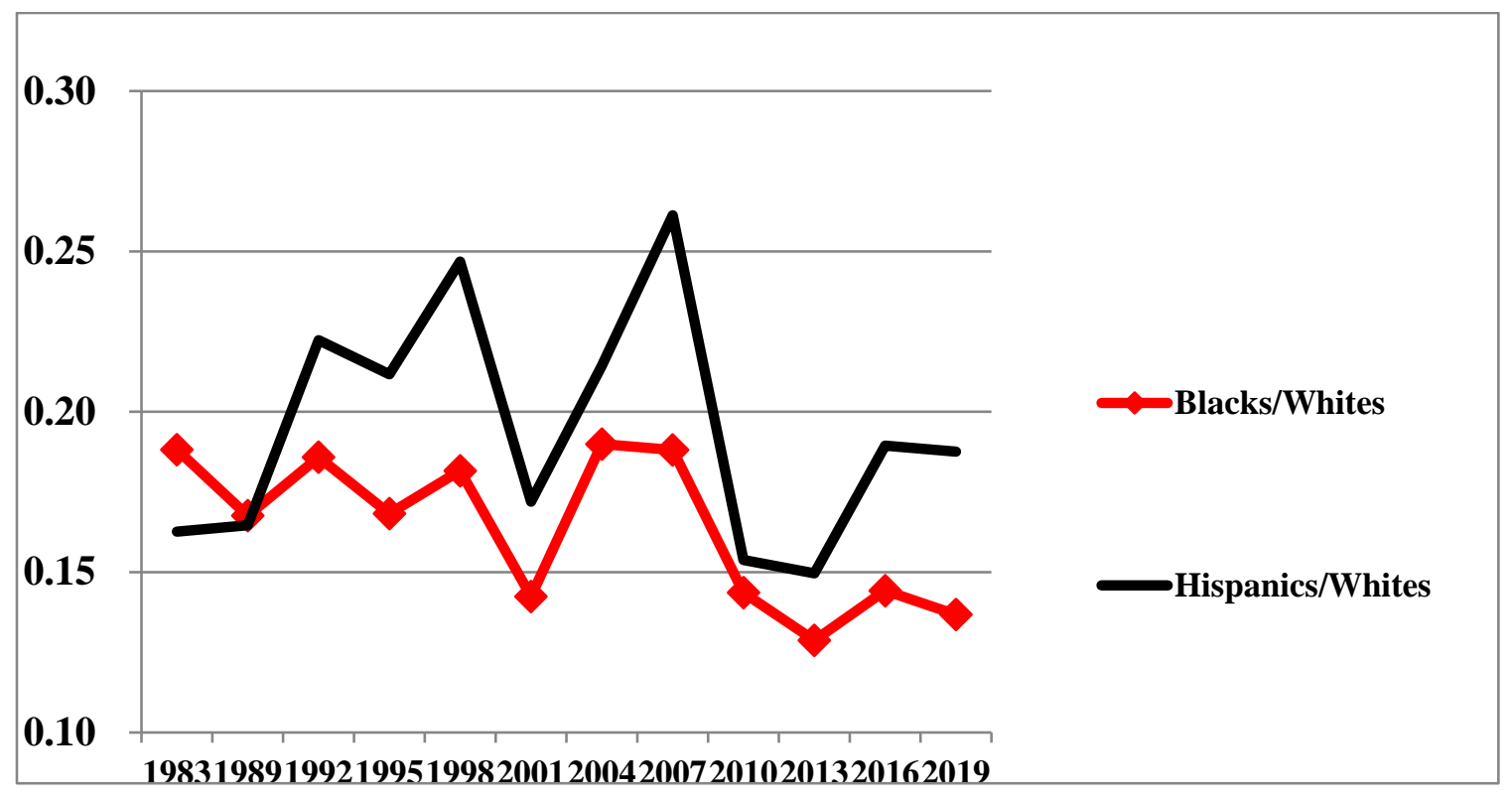

Figure 12. Ratio of Mean Net Worth between Racial and Ethnic Groups, 1983-2019 
[Source: Author's computations from the SCF]

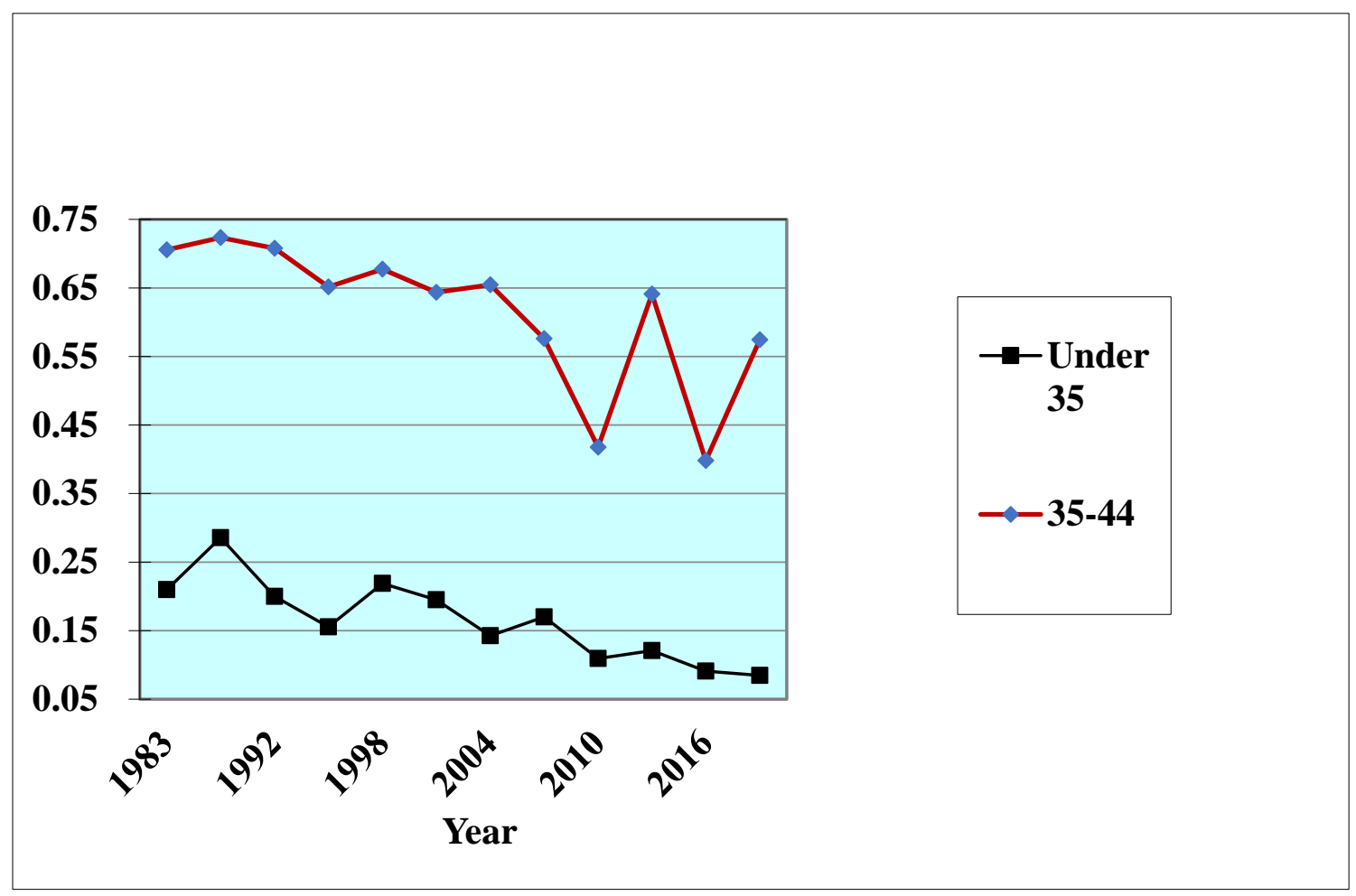

Figure 13. Ratio of Mean Net Worth by Age Group to the Overall Mean, 1983-2019 [Source: Author's computations from the SCF] 
